\title{
PENGARUH SISTEM AKUNTANSI MANAJEMEN DAN PARTISIPASI ANGGARAN TERHADAP KINERJA MANAJERIAL SKPD DI KABUPATEN SIDENRENG RAPPANG
}

\author{
Haslindah \\ Universitas Muslim Indonesia \\ Email: haslindah.pratiwi@yahoo.com \\ Jeni Kamase \\ Universitas Muslim Indonesia \\ Email: jenikamase63@gmail.com \\ Hajering \\ Universitas Muslim Indonesia \\ Email: hajeringmude@gmail.com
}

\begin{abstract}
In this study the author has the objective to determine the effect of management accounting system and budget particiaption on managerial performance on the staff of the Local Government Sidenreng Rappang either partially or simultaneously. The hypothesis of this study is: Suspected of management accounting system and budget particiaption have a significant impact on the performance of managerial staff of the Local Government Sidenreng Rappang either partially or simultaneously. The data required in this study is primary data in the form of respondents' assessment of Management Accounting Systems, Budget Particiaption and Managerial Performance in Local Government Offices Sidenreng Rappang. Data collection methods used in this study is the questionnaire as well as a literature review on the books related to the subject matter covered. Data analysis techniques used by Multiple Linear Regression Test, $t$ test, $F$ test, Coefficient of Determination Test. The results of the data analysis in this study it can be concluded that the management accounting system and budget particiaption have a significant influence on the performance of managerial staff of the Local Government Sidenreng Rappang either partially or simultaneously.
\end{abstract}

Keyword: Management Accounting Systems, Budget Particiaption and Managerial Performance

\begin{abstract}
Abstrak
Penelitian ini bertujuan untuk mengetahui pengaruh sistem akuntansi manajemen dan partisipasi anggaran terhadap kinerja manajerial SKPD di Kabupaten Sidenreng Rappang. Hipotesis penelitian ini adalah sistem akuntansi manajemen dan partisipasi anggaran berpengaruh signifikan terhadap kinerja manajerial SKPD di Kabupaten Sidenreng Rappang. Data yang digunakan dalam penelitian ini adalah data primer dalam bentuk penilaian responden tentang sistem akuntansi manajemen, partisipasi anggaran dan kinerja manajerial SKPD di Kabupaten Sidenreng Rappang. Metode pengumpulan data menggunakan kuisioner dan studi Pustaka. Teknik analisis data menggunakan analisis regresi linear berganda, uji t, uji $\mathrm{F}$ dan uji koefisinen determinasi. Hasil penelitian menemukan bahwa sistem akuntansi manajemen dan partisipasi anggaran berpengaruh signifikan terhadap kinerja manajerial SKPD di Kabupaten Sidenreng Rappang baik secara parsial maupun simultan.
\end{abstract}

Kata kunci: Sistem Akuntansi Manajemen, Partisipasi Anggaran dan Kinerja Manajerial 


\section{PENDAHULUAN}

Kinerja sektor publik sebagian besar dipengaruhi oleh kinerja aparat atau manajerial. Pemerintah daerah sebagai pihak yang diserahi tugas menjalankan roda pemerintahan, pembangunan, dan layanan sosial masyarakat wajib menyampaikan pertanggungjawaban kinerja manajerial pemerintah daerahnya untuk dinilai apakah pemerintah daerah berhasil menjalankan tugasnya dengan baik. Karena di beberapa daerah di Indonesia yang menyebabkan kinerja pemerintah daerah tersebut rendah adalah belum optimalnya proses perencanaan dan penganggaran yang mengabaikan prinsip-prinsip pengelolaan keuangan daerah yang baik. Akibatnya, daya serap yang rendah memunculkan masalah pengelolaan keuangan daerah yang buruk (Nurhalimah, 2013).

$$
\text { Tanpa mengenyampingkan }
$$

kinerja operasional suatu organisasi, keberhasilan suatu organisasi dalam mencapai tujuannya sebagian besar tergantung pada kinerja manajerialnya. Kinerja manajerial dapat dijelaskan sebagai eksistensi kerja manajer (pimpinan) dalam menyelesaikan pekerjaan dengan seefektif mungkin (Soobaroyen dan Poorundersing dalam Rante, dkk, 2014).

Kinerja manajerial merupakan hasil kerja secara kualitas dan kuantitas yang dicapai oleh seseorang manajer dalam melaksanakan tugasnya sesuai dengan tanggung jawab yang diberikan kepadanya (Ingkiriwang, 2013). Ayu dan Dahen (2014) berpendapat bahwa kinerja manajerial merupakan hasil dan keluaran yang dihasilkan oleh manajer sesuai dengan perannya dalam organisasi dalam suatu periode tertentu. Pada umumnya keberhasilan suatu perusahaan banyak tergantung pada faktor-faktor manajerial.

Ada beberapa faktor yang memengaruhi kinerja manajerial pemerintah daerah di antaranya adalah sistem akuntansi manajemen dan panganggaran partisipatif. Sistem akuntansi manajemen menurut Hansen dan Mowen (2009) dalam Qibtiyah (2018), adalah proses yang digambarkan oleh aktivitas-aktivitas seperti pengumpulan, mengukur, mengarsipkan, menganalisis, pelaporan untuk pengelolaan suatu informasi.

Mia dan Chanel dalam Sianipar (2018), mengemukakan bahwa jika para manajer menggunakan informasi yang disediakan oleh sistem akuntansi manajemen maka para manajer tersebut dapat melaksanakan hal yang lebih baik dalam melaksanakan pekerjaan dan perbaikan dalam kinerjanya. Penggunaan sistem akuntansi manajemen perusahaan akan mendapat informasi-informasi yang sangat penting.

Sistem akuntansi manajemen juga dapat memuat informasi-informasi yang dapat dijadikan sebagai dasar untuk program promosi, untuk penjualan, untuk pajak, kategori pelanggan dan tingkat pelanggan. Hal tersebut juga dapat dijadikan sebagai salah satu rencana sarana untuk lebih meningkatkan pelayanan dan kualitas perusahaan itu sendiri. Selanjutnya para manajer yang dapat menggunakan sistem akuntansi manajemen dengan baik, sangat memungkinkan para manajer tersebut untuk melihat dan memastikan apakah perusahaan mereka bersaing dengan perusahaan-perusahaan pesaing mereka, dalam penawaran produk dan pelayanan untuk konsumen berupa harga yang kompetitif, pelayanan 
dan fasilitas yang mereka punya untuk konsumen.

Hasil penelitian Wulandari, dkk (2014), Lempas,dkk (2014), Rante, dkk (2014), dan Damayanti, dkk (2015), menyatakan bahwa sistem akuntansi manajemen berpengaruh positif dan signifikan terhadap kinerja manajerial. Sedangkan Hasil penelitian Qibtiyah (2018), menemukan bahwa sistem akuntansi manajemen berpengaruh negatif terhadap kinerja manajerial. Sementara hasil penelitian Ingkiriwang (2013), menemukan bahwa Sistem Akuntansi Manajemen tidak berpengaruh signifikan terhadap kinerja manajer.

Selain sistem akuntansi manajemen, faktor lainnya adalah interaksi partisipasi penyusunan anggaran. Anggaran adalah suatu rencana keuangan mengenai perkiraan kinerja yang hendak dicapai dalam suatu periode waktu tertentu, sedangkan penganggaran merupakan suatu metode yang digunakan dalam menyusun anggaran (Mardiasmo,2018). Pada anggaran dalam organisasi pemerintah daerah pemanfaatannya terkait pada penentuan jumlah porsi dana dalam membiayai program dan aktivitas yang berasal dari dana milik rakyat. Dalam penyusunan anggaran sektor publik, Komunikasi, koordinasi, dan partisipasi antara atasan dan bawahan yang terkait dengan tujuan organisasi dan isu-isu strategis yang dihadapi masyarakat diperlukan sebagai dasar dalam penyusunan suatu kebijakan, program, dan kegiatan, guna mengetahui informasi yang dibutuhkan. Penganggaran partisipatif memiliki hubungan yang erat dengan kinerja aparat pemerintah daerah.
Menurut goal-setting theory individu akan lebih berkomitmen untuk melaksanakan tujuannya terjadi ketika individu tersebut menetapkan tujuannya sendiri dan bukan diberikan dan ketika tujuan tersebut didasarkan pada setidaknya sebagian dari kemampuan individu (Colbert, 2005 dalam Wibowo, 2017). Dengan kata lain dengan memberikan kesempatan kepada pegawainya untuk dapat menetapkan tujuannya cenderung untuk bekerja lebih baik bila dibandingkan ketika tujuan hanya ditetapkan oleh atasan saja.

Menurut Hansen dan Mowen (2006) dan Wibowo (2017), partisipasi anggaran bila tidak dilaksanakan dengan benar dapat mengakibatkan kegagalan dalam mencapai standar dan akan membuat frustasi bagi para manajer bila diterapkan terlalu ketat, namun bila terlalu mudah dicapai maka akan membuat manajer kehilangan minat dalam bekerja. Akibat lainnya dari penerapan partisipasi anggaran yang kurang benar adalah dapat menyebabkan kesenjangan dalam anggaran dan munculnya partisipasi semu.

Hasil penelitian Hanny (2013), Lina dan Stella (2013), Minai and Mun (2013), dan Windasari (2016), menemukan bahwa partisipasi anggaran memiliki hubungan positif pada kinerja manajerial. Sebaliknya penelitian Hafridebri (2013), Janah dan Rahayu (2015), Andison dan Augustine (2017), dan Ermawati (2017), menemukan bahwa pengaruh penganggaran partisipatif pada kinerja manajerial mempunyai pengaruh tidak signifikan.

Berdasarkan hasil review penelitian terdahulu di atas didapatkan research gap berupa inkonsisten (tidak konsisten) hasil penelitian. Wulandari, 
dkk (2014), Lempas, dkk (2014), Rante, dkk (2014), Damayanti, dkk (2015) dan Qibtiyah (2018) menemukan bahwa sistem akuntansi manajemen berpengaruh positif dan signifikan terhadap kinerja manajerial. Sementara hasil penelitian Ingkiriwang (2013), menemukan bahwa Sistem Akuntansi Manajemen tidak berpengaruh signifikan terhadap kinerja manajer. Hanny (2013), Lina dan Stella (2013), Minai dan Mun (2013), dan Windasari (2016), menemukan bahwa partisipasi anggaran berpengaruh terhadap kinerja manajerial. Sebaliknya penelitian Hafridebri (2013), Janah dan Rahayu (2015), Andison dan Augustine (2017), dan Ermawati (2017), menemukan bahwa partisipasi anggaran tidak berpengaruh terhadap kinerja manajerial.

Berdasarkan gap research diketahui bahwa tidak selalu kinerja manajerial dipengaruhi oleh sistem akuntansi manajemen dan partisipasi anggaran. Oleh karenanya peneliti tertarik untuk kembali menguji pengaruh sistem akuntansi manajemen dan parisipasi anggaran terhadap kinerja manajerial dengan mengambil pemerintah daerah Kabupaten Sidenreng Rappang sebagai objek pengamatan.

Fenomena di Kabupaten Sidenreng Rappang adalah masih terdapat Satuan Kerja Perangkat Daerah (SKPD) yang mengalami kendala dalam hal kekurang lengkapan dokumen pertanggungjawaban maupun keterlambatan penyampaian surat pertanggungjawaban. Selain itu, terdapat ketidak patuhan terhadap ketentuan yang berlaku dalam penyusunan anggaran. Hal ini tentunya dapat menghambat kinerja manajerial SKPD di Kabupaten Sedenreng Rappang.
Berdasarkan uraian di atas, maka dilakukan penelitian dengan fokus "Pengaruh Sistem Akuntansi Manajemen dan Partisipasi Anggaran Terhadap Kinerja Manajerial SKPD Di Kabupaten Sidenreng Rappang."

\section{TINJAUAN PUSTAKA}

\subsection{Teori Penetapan Tujuan (Goal Setting Theory) \\ Goal setting theory yang} dikembangkan oleh Locke sejak 1968 telah mulai menarik minat dalam berbagai masalah dan isu organisasi. Menurut goal setting theory, individu memiliki beberapa tujuan, memilih tujuan, dan mereka termotivasi untuk mencapai tujuan-tujuan tersebut (Srimindarti, 2012). Teori ini mengasumsikan bahwa faktor utama yang memengaruhi pilihan yang dibuat individu adalah tujuan yang mereka miliki. Goal setting theory telah menunjukkan adanya pengaruh signifikan dalam perumusan tujuan (Arsanti, 2009). Kekhususan dan kesulitan merupakan atribut dari penetapan tujuan. Umumnya, semakin sulit dan spesifik tujuan yang ditetapkan, semakin tinggi tingkat prestasi yang akan dihasilkan.

Salah satu karakteristik dari goal setting adalah tingkat kesulitan tujuan. Tingkat kesulitan tujuan yang berbeda akan memberikan motivasi yang berbeda bagi individu untuk mencapai kinerja tertentu. Tingkat kesulitan tujuan yang rendah akan membuat individu memandang bahwa tujuan sebagai pencapaian rutin yang mudah dicapai sehingga akan menurunkan motivasi individu untuk berkreativitas dan mengembangkan kemampuannya. Sedangkan pada tingkat kesulitan tujuan yang lebih tinggi tetapi mungkin untuk 
dicapai, individu akan termotivasi untuk berfikir cara pencapaian tujuan tersebut. Proses ini akan menjadi sarana berkembangnya kreatifitas dan kemampuan individu untuk mencapai tujuan tersebut (Ginting dan Ariani dalam Matana, 2017).

Goal setting theory atau teori penetapan tujuan adalah proses kognitif membangun tujuan dan merupakan determinan perilaku. Prinsip dasar goal setting theory adalah goals dan intentions, yang keduanya merupakan penanggung jawab untuk human behavior. Dalam studi mengenai goal setting, goal menunjukkan pencapaian standar khusus dari suatu keahlian terhadap tugas dalam batasan waktu tertentu. Harder goal akan dapat tercapai bila ada usaha dan perhatian yang lebih besar dan membutuhkan lebih banyak knowledge dan skill daripada easy goal.

Mengacu pada Locke's model (Arsanti, 2009), goal setting theory atau teori penetapan tujuan mempunyai empat mekanisme dalam memotivasi individu untuk mencapai kinerja. Pertama, penetapan tujuan dapat mengarahkan perhatian individu untuk lebih fokus pada pencapaian tujuan tersebut. Kedua, tujuan dapat membantu mengatur usaha yang diberikan oleh individu untuk mencapai tujuan. Ketiga, adanya tujuan dapat meningkatkan ketekunan individu dalam mencapai tujuan tersebut. Keempat, tujuan membantu individu untuk menetapkan strategi dan melakukan tindakan sesuai yang direncanakan. Dengan demikian, dengan adanya penetapan tujuan dapat meningkatkan kinerja individu yang pada akhirnya akan meningkatkan kinerja perusahaan.

Komitmen harus ada dalam goal setting. Komitmen terhadap goal nampak secara langsung dan tidak langsung berpengaruh pada performance. Bila person's goal tinggi, maka high commitment akan membawa pada higher performance dibandingkan ketika low commitment. Tetapi, bila goals rendah, high commitment membatasi performance. Ginting dan Ariani dalam Matana (2017), menyatakan bahwa goal commitment berdampak pada proses goal setting yang akan berkurang bila ada goal conflict. Goal commitment berhubungan positif dengan goal directed behavior, dan goal directed behavior berhubungan positif dengan performance.

\subsection{Sistem Akuntansi Manajemen}
a. Teori dan Definisi Akuntansi Manajemen

Sistem informasi akuntansi manajemen adalah sistem informasi yang menghasilkan keluaran (output) dengan menggunakan masukan (input) dan memprosesnya untuk mencapai tujuan khusus manajemen. Hansen dan Mowen (2006) dalam Kumentas (2013), Sistem Akuntansi Manajemen mempunyai tiga tujuan yaitu menyediakan jasa informasi yang digunakan dalam perhitungan jasa, produk, dan tujuan lain yang diinginkan manajemen, untuk menyediakan informasi yang digunakan dalam perencanaan, pengendalian, dan pengevaluasian dan untuk menyediakan informasi yang berguna dalam pengambilan keputusan.

b. Pengertian Sistem Akuntansi Manajemen

Sistem akuntansi manajemen adalah salah satu bidang akuntansi yang tujuan utamanya untuk menyajikan informasi yang berguna dalam satuan usaha atau organisasi tertentu untuk kepentingan internal dalam rangka 
melaksanakan proses manajemen yang meliputi perencanaan, pembuatan keputusan, pengorganisasian, pengarahan dan pengendalian (Solechan, 2007 dalam Sianipar, 2018). Garrison dan Noreen (2000) dalam Sianipar (2018), menyatakan bahwa sistem akuntansi manajemen adalah akuntansi yang berkaitan dengan penyediaan informasi kepada para manajer untuk membuat perencanaan dan pengendalian operasi serta dalam pengambilan keputusan. Sistem akuntansi manajemen menggambarkan sebuah sistem yang didesain untuk menyediakan informasi untuk manajer. Sistem akuntansi manajemen merupakan bagian dari sistem pengendalian organisasi yang perludiperhatikan karena diharapkan dapat memberikan kontribusi yang positif didalam keberhasilan sistem pengendalian manajemen. Sistem akuntansi manajemen membantu manajer untuk mengendalikan aktivitas perusahaan sehingga dapat membantu perusahaan dalam mencapai tujuan perusahaan.

Astuti (2007) dalam Sianipar (2018), menyatakan bahwa sistem akuntansi manajemen adalah sistem informasi yang mengumpulkan data operasional dan finasial, memprosesnya, menyimpannya dan melaporkan kepada pengguna. Produk yang dihasilkan oleh sistem akuntansi manajemen adalah informasi akuntansi manajemen.

Prasetyo (2006) dalam Sianipar (2018), mengemukakan sistem akuntansi manajemen merupakan salah satu mekanisme pengendalian di dalam organisasi, serta alat yang efektif di dalam menyediakan informasi yang bermanfaat guna memprediksi konsekuensi yang mungkin terjadi dari berbagai aktivitas yang bisa dilakukan.
Salah satu produk yang dihasilkan sistem akuntansi manajemen adalah informasi akuntansi manajemen yang berguna untuk membantu pekerja, manajer dan eksekutif untuk membuat keputusan yang lebih baik.

Sistem akuntansi manajemen dalam organisasi merupakan berperan membantu manajer atau orang-orang yang bertanggungjawab dalam pelaksanaan aktivitas-aktivitas perencanaan, pengorganisasian, pengarahan dan pengambilan keputusan. Sistem akuntansi manajemen merupakan sistem formal yang dirancang untuk menyediakan informasi untuk pengguna internal seperti manajer, eksekutif, dan para pekerja. Sistem akuntansi manajemen secara khusus akan menerapkan teknik-teknik dan konsep yang tepat dalam pengolahan data ekonomi historicaldan yang diproyeksikan dari satu satuan usaha untuk membantu manajemen dalam penyusunan rencana untuk tujuantujuan ekonomi yang rasional dan dalam membuat keputusan-keputusan rasional dengan satu pandangan kearah pencapai tujuan (Lempas \& Sabijono, 2014).

Sistem akuntansi manajemen yang merupakan bagian dari sistem pengendalian organisasi perlu mendapat perhatian, hingga dapat diharapkan akan memberikan kontribusi positif dalam mendukung keberhasilan sistem pengendalian manajemen (Lempas \& Sabijono, 2014). Sistem akuntansi manajemen yaitu suatu sistem pengolahan informasi keuangan yang digunakan untuk menghasilkan informasi keuangan bagi kepentingan pemakai intern organisasi (Mulyadi, 1997 dalam Setyolaksono, 2011). 
c. Karakteristik Pengukuran Sistem Akuntansi Manajemen

Chenhall dan Morris (1986) dalam Setyolaksono (2011), mengidentifikasi empat karakteristik informasi sistem akuntansi manajemen yaitu sebagai berikut:

\section{1) Broadscope}

Lingkup sistem akuntansi manajemen yang luas memberikan informasi yang berhubungan dengan lingkungan eksternal yang mungkin bersifat ekonomi seperti Gross National Product, total penjualan pasar dan pangsa pasar suatu industri, atau juga bersifat non ekonomi seperti faktor demografi, cita rasa konsumen, tindakan para pesaing dan perkembangan teknologi. Disamping itu, lingkup sistem akuntansi manajemen yang luas akan memberikan estimasi tentang kemungkinan terjadinya peristiwa di masa yang akan dating dalam ukuran probabilitas.

\section{2) Timeliness}

Informasi

timeliness

meningkatkan fasilitas sistem akuntansi manajemen untuk melaporkan peristiwa paling akhir dan untuk memberikan umpan balik secara tepat terhadap keputusan yang dibuat. Jadi timeliness mencakup frekuensi pelaporan dan kecepatan pelaporan.

\section{3) Aggregation}

Tipe aggregasi yang mangacu pada berbagai format yang konsisten dengan model keputusan formal seperti analisis cash flow yang didiskontokan untuk anggaran modal, simulasi dan linier programming untuk penerapan anggaran, analisis laba dan rugi dan analisis pengendalian intern.

4) Integration

Aspek pengendalian suatu organisasi yang penting adalah koordinasi berbagai segmen dalam subsub organisasi. Karakteristik sistem akuntansi manajemen yang membantu koordinasi mencakup spesifikasi target yang menunjukkan pengaruh interaksi segmen dan informasi mengenai pengaruh keputusan pada operasi seluruh sub unit organisasi.

\subsection{Partisipasi Anggaran}

\section{a. Definisi Anggaran}

Manajemen dalam mengelola suatu perusahaan terlebih dahulu menetapkan tujuan dan sasaran, untuk mencapai tujuan dan sasaran tersebut manajemen membuat rencana kegiatan. Rencana yang disusun dalam satuan moneter dituangkan dalam bentuk anggaran.Rahayu dan Andry (2013) menyimpulkan bahwaanggaran merupakan alat bagi manajemen yang memegang peranan penting dalam sistem pengendalian manajemen sebuah perusahaan, terutama dalam proses perencanaan (planning) dan pengawasan (controlling). Anggaran merupakan rencana dari seluruh kegiatan perusahaan dalam jangka pendek yang dinyatakan dalam unit kuantitatif.

Menurut Nafarin (2015), anggaran merupakan rencana tertulis mengenai kegiatan suatu organisasi yang dinyatakan secara kuantitatif untuk jangka waktu tertentu dan umumnya dinyatakan dalam satuan uang, tetapi dapat juga dinyatakan dalam satuan barang/jasa. Menurut Mulyadi (2002) dalam Aprilianisa (2018), anggaran merupakan suatu rencana kerja yang dinyatakan secara kuantitatif, yang diukur dalam satuan moneter standar dan satuan ukuran yang lain, yang mencakup jangka waktu satu tahun.

Kemudian menurut Dharmanegara (2010), anggaran merupakan suatu 
rencana yang disusun secara sistematis, yang meliputi seluruh kegiatan perusahaan, yang dinyatakan dalam unit (satuan) moneter dan berlaku untuk jangka panjang.

Dari definisi-definisi diatas dapat disimpulkan bahwa anggaran merupakan rencana tertulis secara kuantitatif dalam suatu periode tertentu yang diukur dalam satuan moneter dan satuan non moneter untuk menunjukan perolehan dan penggunaan sumber daya dalam kegiatan operasional organisasi sebagai upaya mencapai tujuan organisasi.

\section{b. Jenis Anggaran}

Terdapat beberapa jenis anggaran yang diungkapkan Anthony dan Govindarajan yang dialih bahasakan oleh F.X Kurniawan (2005) dalamAprilianisa (2018), yaitu:

1) Anggaran Operasi

Anggaran operasi adalah rencana kerja perusahaan yang mencakup semua kegiatan utama perusahaan dalam memperoleh pendapatan di dalam suatu periode tertentu.

2) Anggaran Modal

Anggaran modal adalah proses pengambilan keputusan yang berkaitan dengan investasi dalam aktiva tetap.

3) Anggaran Neraca

Anggaran neraca adalah anggaran yang memerinci taksiran keadaan aktiva atau asset dan pasiva atau kewajiban serta kekayaan bersih dalam suatu kurun masa yang akan datang.

4) Anggaran Laporan Arus Kas

Anggaran laporan arus kas adalah anggaran yang memerinci taksiran penerimaan dan pengeluaran uang tunai dalam suatu kurun masa yang akan dating.
Sedangkan Nafarin (2015),

mengkelompokan anggaran menjadi

beberapa jenis angggaran berdasarkan:

1) Segi dasar penyusunan

Dilihat dari segi penyusunan, anggaran terdiri atas:

a) Anggaran Variabel

Anggaran variabel adalah anggaran yang disusun berdasarkan interval (kisaran) kapasitas (aktivitas) tertentu pada intinya merupakan suatu seri anggaran yang dapat disesuaikan pada tingkat aktivitas (kegiatan) yang berbeda

b) Anggaran Tetap

Anggaran tetap adalah anggaran yang disusun berdasarkan suatu kapasitas tertentu.

2) Segi cara penyusunan

Dilihat dari segi cara penyusunan, anggaran terdiri atas:

a) Anggaran Periodik

Anggaran periodik adalah anggaran yang disusun untuk satu periode tertentu.

b) Anggaran Kontinyu

Anggaran kontinyu adalah anggaran yang dibuat untuk mengadakan perbaikan atas anggaran yang pernah dibuat.

3) Segi jangka waktu

Dilihat dari segi jangka waktu, anggaran terdiri atas:

a) Anggaran Jangka Pendek

Anggaran jangka pendek adalah anggaran yang dibuat dengan jangka waktu paling lama sampai satu tahun.

b) Anggaran Jangka Panjang

Anggaran jangka panjang adalah anggaran yang dibuat dengan jangka waktu lebih dari satu tahun.

4) Segi bidang

Dilihat dari segi bidangnya, anggaran terdiri atas: 

a) Anggaran Operasional
Anggaran operasional adalah anggaran untuk menyusun anggaran laba rugi.
b) Anggaran Keuangan

$\begin{array}{llr}\text { Anggaran keuagan } & \text { adalah } \\ \text { anggaran untuk } & \text { menyusun } \\ \text { anggaran neraca. } & \end{array}$

5) Kemampuan menyusun

Dilihat dari segi kemampuan menyusun, anggaran terdiri atas:

a) Anggaran Komprehensif

Anggaran komprehensif adalah rangkaian dari berbagai jenis anggaran yang disusun secara lengkap. Anggaran komprehensif merupakan gabungan dari anggaran operasional dan anggaran keuangan secara lengkap.

b) Anggaran Parsial

Anggaran parsial adalah anggaran yang disusun secara tidak lengkap atau anggaran yang hanya menyusun bagian anggaran tertentu saja.

6) Segi fungsi

Dilihat dari segi fungsi, anggaran terdiri atas:

a) Anggaran Tertentu

Anggaran tertentu adalah anggaran yang diperuntukan bagi tujuan tertentu dan tidak boleh digunakan untuk manfaat lain.

b) Anggaran Kinerja

Anggaran kinerja adalah anggaran yang disusun berdasarkan fungsi kegiatan yang dilakukan dalam organisasi (perusahaan), misalnya untuk menilai apakah biaya (beban) yang dikeluarkan oleh masing-masing aktivitas tidak melampaui batas.

7) Segi metode penentuan harga pokok produk Dilihat dari segi metode penentuan harga pokok produk, anggaran terdiri atas:

a) Anggaran Tradisional

Anggaran tradisional terdiri atas:

(1) Anggaran berdasar fungsional Anggaran berdasar fungsional adalah anggaran yang dibuat dengan menggunakan metode penghargapokokan penuh (full costing) dan berfungsi untuk menyusun anggaran induk atau anggaran tetap.

(2) Anggaran berdasar sifat Anggaran berdasar sifat adalah anggaran yang dibuat dengan menggunakan metode penghargapokokan variabel (variable costing) dan berfungsi untuk menyusun anggaran variabel.

b) Anggaran berdasar kegiatan

Anggaran berdasar kegiatan adalah anggaran yang dibuat dengan menggunakan metode penghargapokokan berdasar kegiatan dan berfungsi untuk menyusun anggaran variabel dan anggaran induk.

\section{c. Fungsi Anggaran}

Menurut Rudiantoro (2013), fungsi anggaran, sebagai berikut:

1) Alat perencanaan

Sebagai bagian dari fungsi perencanaan (planning, anggaran merupakan rencana kerja yang menjadi pedoman bagi anggota organisasi dalam bertindak. Dalam fungsi perencanaan anggaran memiliki beberapa manfaat yang saling terkait satu dengan lainnya, yaitu:

a) Memberikan pendekatan yang terarah dan terintegrasi kepada seluruh anggota organisasi. 
b) Menciptakan suasana organisasi yang mengarah pada tujuan umum, yaitu pencapaian laba usaha.

c) Memaksa seluruh anggota organisasi untuk memiliki komitmen mencapai sasaran yang telah diciptakan.

d) Mengarahkan penggunaan seluruh sumber daya pada kegiatan yang paling menguntungkan.

e) Mendorong pencapaian standar prestasi yang tinggi bagi seluruh anggota organisasi.

2) Alat pengendalian

Sebagai bagian dari fungsi pengendalian (controlling), anggaran berguna sebagai alat penilai apakah aktivitas setiap bagian organisasi telah sesuai dengan rencana atau tidak. Dalam fungsi pengendalian, anggaran memiliki beberapa manfaat yang saling terkait satu dengan lainnya, yaitu:

a) Berperan sebagai tolok ukur atau standar bagi kegiatan organisasi.

b) Memberikan kesempatan untuk menilai dan mengevaluasi secara sistematik setiap segi atau aspek organisasi.

c) Mendorong pihak manajemen secara dini mengadakan penelaahan terhadap masalah yang dihadapi.

Rahayu dan Andry (2013) menjelaskan beberapa fungsi anggaran dalam proses manajemen adalah sebagai berikut:

1) Berhubungan dengan planning.

a) Membantu manajemen meneliti dan mempelajari segala masalah yang berkaitan dengan aktivitas yang akan dilaksanakan.

b) Membantu mengarahkan seluruh sumber daya yang ada di perusahaan dalam menentukan arah atau aktivitas yang paling menguntungkan. c) Membantu arah atau menunjang kebijaksanaan perusahaan.

d) Membantu manajemen memilih tujuan perusahaan.

e) Membantu menstabilkan kesempatan kerja yang tersedia.

f) Membantu pemakaian alat-alat fisik secara lebih efektif.

2) Berhubungan dengan coordinating.

a) Membantu mengkoordinir faktor sumber daya manusia dengan perusahaan.

b) Membantu menilai kesesuaian antara rencana aktivitas perusahaan dengan keadaan lingkungan usaha yang dihadapi.

c) Membantu menempatkan pemakaian modal pada saluransaluran yang menguntungkan sesuai dan seimbang dengan program perusahaan.

d) Membantu mengetahui kelemahan dalam organisasi.

3) Berhubungan dengan motivasi, anggaran memotivasi para pelaksananya dalam melaksanakan tugas-tugas untuk mencapai tujuan.

4) Berhubungan dengan komunikasi, anggaran meliputi penyampaian informasi yang berhubungan dengan tujuan, strategi, kebijakasanaan, dan penyimpangann yang terjadi.

5) Berhubungan dengan controlling (pengendalian dan evaluasi).

a) Membantu mengawasi kegiatan dan pengeluaran.

b) Membantu mencegah pemborosan.

c) Membantu menetapkan standar baru.

6) Berhubungan dengan pendidikan, anggaran mendidik para manajer mengenai bagaimana bekerja secara terinci pada pusat pertanggungjawab yang dipimpin. 


\section{d. Hubungan Anggaran dengan Akuntansi}

Menurut Rahayu dan Andry (2013), penganggaran dan akuntansi mempunyai hubungan yang tidak dapat dipisahkan satu dengan lainnya. Hubungan keduanya tersebut dijelaskan sebagai berikut:

1) Akuntansi menyediakan data historis yang dapat digunakan untuk tujuan analisis dalam menyusun rencana perusahaan (anggaran).

2) Komponen penganggaran yang dinyatakan secara finansial, disusun dalam format akuntansi dengan menggunakan sistem informasi yang sama.

3) Akuntansi menyediakan data aktual untuk dibandingkan dengan data anggaran sebagai dasar untuk evaluasi kinerja (performance report).

Menurut Nafarin penganggaran memang berkaitan secara unik dengan sistem akunting dalam hal:

1) Komponen keuangan dari suatu anggaran yang umumnya disusun dalam satuan format akunting.

2) Penganggaran berkaitan erat dengan akunting manajemen, yaitu berupa akunting harga pokok standar dan akunting penentuan biaya variabel (variable costing). Penganggaran juga merupakan bagian dari akunting manajemen.

3) Akunting keuangan mencatat transaksi di masa lalu, sedangkan penganggaran mencatat transaksi di masa mendatang. Dalam hal ini anggaran merupakan pedoman dalam pelaksanaan transaksi keuangan

4) Untuk membandingkan anggaran dengan realisasi diperlukan data yang dihasilkan oleh akunting keuangan.
5) Penganggaran merupakan perencanaan akunting, sedangkan akunting keuangan merupakan pelaksanaan akunting.

6) Akunting keuangan memberikan masukan data historis yang relevan terutama untuk tujuan analisis dalam pengembangan anggaran.

\section{e. Pendekatan Penyusunan Anggaran}

Anthony dan Govindarajan (2005) dalamAprilianisa (2018), menyatakan bahwa terdapat tiga pendekatan yang digunakan dalam penyusunan anggaran, yaitu:

1) Pendekatan dari atas ke bawah (top down approach).

2) Pendekatan dari bawah ke atas (bottom up approach).

3) Pendekatan lain merupakan gabungan dari kedua pendekatan tersebut, yaitu pendekatan partisipasi.

Pendekatan penyusunan anggaran menggunakan top down approach, jika anggaran ditentukan oleh manajer tingkat atas, sedangkan bottom up approach dimana anggaran disiapkan oleh pihak-pihak yang melaksanakan anggaran tersebut. Pendekatan partisipasi adalah gabungan dari pendekatan top-down dan bottom-up. Pendekatan partisipasi ini dianggap sebagai pendekatan yang paling efektif karena kerjasama dan interaksi antara atasan dan bawahan dalam menyusun anggaran akan menghasilkan anggaran yang benar-benar mendapat dukungan dari kedua belah pihak sehingga diharapkan ada komitmen yang kuat untuk melaksanakannya.

Partisipasi anggaran memerlukan kerjasama dari berbagai tingkat manajemen untuk mengembangkan rencana anggaran. Setiap tingkatan tanggung jawab dalam suatu organisasi 
harus memberikan masukan terbaik sesuai dengan bidangnya dalam suatu sistem kejasama penyusunan anggaran. Hal ini karenamanajer puncak biasanya tidak menetahui mengenai kegiatan sehari-hari pada level bawah, sehingga membutuhkan informasi yang lebih handal dari bawahannya.

Menurut Dharmanegara (2010), pendekatan yang dilakukan dalam proses penyusunan penganggaran, dibagi menjadi dua yaitu:

1) Penganggaran Top Down

Yaitu pendekatan yang lebih otoritarian dari penganggaran. Pendekatan ini mengambil sedikit tempat negosiasi di antara manajer junior dan manajer senior. Pendekatan ini memiliki manfaat yang relatif cepat dan efisien serta mencerminkan perspektif manajemen puncak dari awal. Proses penyusunan anggaran yang tidak melibatkan bawahan secara signifikan. Disini manajemen puncak menentukan besarnya anggaran yang harus digunakan dan dialokasikan ke manajer dibawahnya tanpa menilai layak tidaknya anggaran yang diberikan. Model ini tidak efektif karena menimbulkan banyak konflik antar manajer, juga menyebabkan manajemen puncak sebagai penyusun anggaran tidak memahami betul mengenai kondisi dan keadaan usaha disetiap divisi.

2) Penganggaran Bottom $U p$

Yaitu pendekatan yang memungkinkan setiap individu mengetahui mengenai departemen mereka. Penganggaran bottom up atau partisipasi adalah penyusunan anggaran yang mengijinkan manajer lebih bawah untuk berpartisipasi secara signifikan dalam pembentukan anggaran. Manajer lini membuat anggaran berdasarkan situasi tanpa tekanan dari manapun termasuk dari manajemen puncak.

Kemudian, anggaran tersebut dikomunikasikan dengan manajer di atasnya. Selanjutnya, anggaran tersebut didiskusikan dengan manajer puncak untuk dievaluasi dan jika disetujui langsung dialokasikan ke pos-pos dan dilaksanakan".

\section{f. Definisi Partisipasi Anggaran}

Keberhasilan suatu organisasi dapat dilihat dari bagaimana cara pembuatan anggaran itu sendiri. Anggaran merupakan perencanaan dalam bentuk finansial, agar tujuan organisasi dapat dicapai dengan baik, maka dalampenyusunan anggaran harus melibatkan para manajer dalam tanggungjawab pengendalian biaya untuk estimasi anggaran mereka sendiri.

Menurut Dharmanegara (2010), partisipasi anggaran dapat diartikan dengan adanya keterlibatan upaya dan input oleh manajer dalam penyusunan anggaran. Rahayu dan Andry (2013), berpendapat bahwa penganggaran partisifatif (participative budgeting) merupakan proses penyusunan anggaran yang melibatkan seluruh karyawan (manajer pada semua tingkatan) dalam organisasi. Di dalam penganggaran partisipatif melibatkan dan adanya pengaruh individu dalam proses penyusunan anggaran.

Menurut Mulyadi

dalamAprilianisa (2018), partisipasi dalam penyusunan anggaran berarti keikutsertaan operating managers dalam memutuskan bersama dengan komite anggaran mengenai rangkaian kegiatan di masa yang akan ditempuh oleh operating managers tersebut dalam pencapaian sasaran anggaran.Menurut Hansen dan Mowen (2013), partisipasi anggaran adalah pendekatan 
penganggaran yang memungkinkan para manajer yang akan bertanggungjawab atas kinerja anggaran, untuk berpartisipasi dalam pengembangan anggaran, partisipasi anggaran mengkomunikasikan rasa tanggung jawab kepada para manajer tingkat bawah dan mendorong kreativitas.

Dari definisi-definisi tersebut dapat disimpulkan bahwa partisipasi anggaran adalah keikutsertaan para manajer dalam proses penyusunan anggaran untuk memperoleh kesepakatan bersama mengenai rangkaian kegiatan yang akan dilakukan.

\section{g. Keunggulan Partisipasi Anggaran}

Keunggulan partisipasi anggaran menurut Garrison, dkk yang diterjemahkan oleh Nuri Hinduan (2006) dalam Aprilianisa (2018), adalah sebagai berikut:

1) Setiap orang pada semua tingkatan organisasi diakui sebagai anggota tim yang pandangan dan penilaiannya dihargai oleh manajemen puncak.

2) Perkiraan anggaran disiapkan oleh manajer level bawah yang lebih akurat dan dapat diandalkan dari perkiraan yang disiapkan oleh level atas yang memiliki pengetahuan kurang detail mengenai pasar dan operasi sehari-hari.

3) Motivasi pada umumnya lebih tinggi ketika individu berpartisipasi dalam menetapkan tujuan mereka sendiri daripada ketika tujuan yang dipaksakan oleh atasan.

4) Manajer yang tidak mampu memenuhi anggaran yang dipaksakan oleh atasan akan selalu mengatakan bahwa anggaran tidak realistis dan mustahil untuk dicapai.

Sementara Anthony dan Govindarajan yang dialih bahasakan oleh
F.X Kurniawan (2005) dalam Aprilianisa (2018), berpendapat anggaran partisipatif memilki keunggulan yaitu:

1) Tujuan anggaran akan lebih mudah diterima apabila anggaran tersebut berada di bawah pengawasan manajer.

2) Anggaran partisipatif menghasilkan pertukaran informasi yang efektif antara pembuat anggaran dan pelaksana anggaran yang dekat dengan produk dan pasar.

\section{h. Kelemahan Partisipasi Anggaran}

Menurut Hansen dan Mowen yang dialih bahasakan oleh Dewi Fitriasari dan Deny Arnos Kwary (2004) dalam Aprilianisa (2018), ada tiga masalah yang timbul yang menjadi kelemahan dalam partisipasi anggaran, antara lain:

1) Pembuatan standar yang terlalu tinggi atau rendah, sejak yang dianggarkan menjadi tujuan manajer.

2) Slack anggaran, adalah perbedaan antara jumlah sumber daya yang sebenarnya diperlukan untuk menyelesaikan tugas secara efisiendengan jumlah yang diajukan oleh manajer yang bersangkutan untuk mengerjakan tugas yang sama.

3) Pseudoparticipation, atau partisipasi semu yang mempunyai arti bahwa perusahaan menggunakan partisipasi dalam penyusunan anggaran padahal sebenarnya tidak. Dalam hal ini bawahan terpaksa menyatakan persetujuan terhadap keputusan yang akan diterapkan karena perusahaan membutuhkan persetujuan mereka.

\section{i. Fasilitas Proses Penyusunan Anggaran}

Horngren, dkk (2016), menyebutkan fasilitas proses penyusunan anggaran adalah:

1) Komunikasi 
Proses anggaran yang paling efektif memfasilitasi komunikasi baik atas ke bawah maupun dari bawah ke atas. Manajemen puncak mengkomunikasikan sasaran dan tujuan anggarannya. Manajer tingkat bawah dan karyawan mengkontribusikan idenya sendiri dan menerima umpan balik atas sasaran dan tujuan. Menurut uraian tersebut penulis menyimpulkan yang menjadi indikator dari komunikasi adalah:

a) Menerima sasaran dan tujuan strategis dalam bentuk anggaran dari manajemen puncak.

b) Memiliki kesempatan dan ikut serta untuk mengkontribusikan idenya sendiri.

c) Menerima umpan balik atas tujuan dan sasaran anggaran.

1) Koordinasi

Proses anggaran yang paling efektif memfasilitasi koordinasi untuk membantu manajer mengkoordinasi aktivitas departemennya dengan departemen lain dan perusahaan secara keseluruhan. Menurut uraian tersebut penulis menyimpulkan yang menjadi indikator dari koordinasi adalah:

a) Mengajak diskusi tentang anggaran dengan departemen lain

b) Mengajak diskusi tentang anggaran dengan perusahaan secara keseluruhan

\section{j. Mekanisme Partisipasi Anggaran di Pemerintah}

Berdasarkan

Peraturan

Pemerintah nomor 58 tahun 2005 tentang Pengelolaan Keuangan Daerah, masing-masing Satuan Kerja Pemerintah Daerah (SKPD) diwajibkan untuk membuat Rencana Kerja (Renja SKPD) sebagai salah satu dasar untuk menyusun Rencana Anggaran
Pendapatan dan Belanja Daerah (RAPBD).

Renja SKPD adalah satu dokumen perencanaan yang dibuat oleh SKPD untuk periode satu tahun anggaran yang memuat kebijakan, program dan kegiatan pembangunan baik yang dilaksanakan oleh pemerintah daerah ataupun yang ditempuh dengan mendorong partisipasi masyarakat.

Dalam penyusunan Renja SKPD masing-masing pejabat struktural di dalam SKPD dapat mengusulkan program dan kegiatan yang mengacu pada hasil musrenbang kecamatan atau hasil evaluasi pelaksanaan Renja SKPD tahun sebelumnya. Usulan tersebut kemudian akan dibahas di dalam forum SKPD. Forum SKPD merupakan wadah penampungan dan penjaringan aspirasimasyarakat dan dunia usaha (stakeholder) dengan tujuan penyempurnaan rancangan kebijakan penyusunan Renja SKPD.

Renja SKPD yang telah disetujui oleh kepala daerah akan digunakan sebagai dasar bagi pemerintah daerah dalam menyusun Rencana Anggaran Pendapatan dan Belanja Daerah (RAPBD). Berdasarkan Permendagri No. 30 tahun 2007 tentang Pedoman Penyusunan Anggaran Pendapatan dan Belanja Daerah menjelaskan bahwa di dalam pembuatan RAPBD perlu memperhatikan prinsip-prinsip penyusunan anggaran yaitu sebagai berikut.

1) Partisipasi stakeholder

Proses penyusunan dan penetapan APBD sedapat mungkin melibatkan partisipasi stakeholder sehingga mereka mengetahui akan hak dan kewajibannya dalam pelaksanaan APBD.

2) Transparansi dan akuntabilitas anggaran 
APBD yang disusun harus dapat menyajikan informasi secara terbuka dan mudah diakses oleh stakeholder yang meliputi tujuan, sasaran, sumber pendanaan pada setiap jenis belanja serta korelasi antara besaran anggaran dengan manfaat dan hasil yang ingin dicapai dari suatu kegiatan yang dianggarkan. Oleh karena itu, setiap pengguna anggaran harus bertanggung jawab terhadap pengguna sumber daya yang dikelola untuk mencapai hasil yang ditetapkan.

3) Disiplin anggaran

Penganggaran pengeluaran harus didukung dengan adanya kepastian tersediannya penerimaan dalam jumlah yang cukup dan tidak dibenarkan melaksanakan kegiatan yang belum tersedia atau tidak mencukupi kredit anggarannya dalam APBD/Perubahan APBD.

4) Keadilan anggaran

Dalam mengalokasikan belanja daerah, harus mempertimbangkan keadilan dan pemerataan agar dapat dinikmati oleh seluruh lapisan masyarakat tanpa diskriminasi pemberian pelayanan.

5) Efisiensi dan efektifitas anggaran

Dana yang tersedia harus dimanfaatkan seoptimal mungkin untuk meningkatkan pelayanan dan kesejahteraan stakeholder. Oleh karena itu, untuk meningkatkan efisiensi dan efektivitas anggaran, dalam perencanaan anggaran perlu memperhatikan; tujuan, sasaran, hasil dan manfaat, serta indikator kinerja yang ingin dicapai, penetapan prioritas kegiatan dan penghitungan beban kerja, serta penetapan harga satuan yang rasional.

6) Taat azas

APBD tidak bertentangan dengan kepentingan umum, lebih diarahkan agar mencerminkan keberpihakan kepada kebutuhan dan kepentingan publik.

\subsection{Kinerja Manajerial}

Kinerja adalah hasil kerja secara kualitas dan kuantitas yang dicapai oleh seseorang dalam melaksanakan tugasnya sesuai dengan tanggung jawab yang diberikan kepadanya (Anwar Prabu Mangkunegara, 2004 dalam Sianipar, 2018). Wirawan (2009) dalam Sianipar (2018), menerangkan kinerja sebagai keluaran yang dihasilkan oleh fungsifungsi atau indikator-indikator suatu pekerjaan atau profesi dalam waktu tertentu. Menurut Wibowo (2010) kinerja adalah hasil pekerjaan.

Manajer adalah individu yang bertanggung jawab secara langsung untuk memastikan kegiatan dalam sebuah organisasi yang dijalankan bersama para anggota organisasi (Sule dan Saefullah, 2005 dalam Sianipar, 2018). Menurut Jeff Madura (2007) dalam Sianipar (2018), manajer adalah karyawan yang bertanggung jawab untuk mengatur pekerjaan karyawan lain (bawahannya) dan membuat keputusan bisnis penting. Jadi, manajer adalah individu yang mengatur karyawan, memastikan seluruh aktivitas dalam perusahaan dan membuat keputusan penting bagi perusahaan.

Menurut Mangkunegara (2005) dalam Sigillipu (2013), kinerja manajerial merupakan suatu proses kombinasi yang terus-menerus dilakukan dalam kerjasama antara seorang karyawan dan aturan langsung yang melibatkan penerapan pengharapan, serta pengertian tentang fungsi kerja karyawan. Kinerja manajerial yang diperoleh manajer juga merupakan salah satu faktor yang dapat dipakai untuk meningkatkan keefektifan 
perusahaan kinerja manajerial menurut Anwar dalam Marthin, dkk (2013), kinerja manajerial merupakan proses perencanaan, pengorganisasian, pelaksanaan, dan pengendalian terhadap pencapaian kinerja dan dikomunikasikan secara terus menerus oleh pimpinan kepada karyawan, antara karyawan dengan atasannya langsung. Sedangkan menurut Yuliana, dkk (2012), kinerja manajerial adalah kinerja para individu anggota sebuah organisasi dalam kegiatan-kegiatan manajerial.

Untuk dapat memperoleh kinerja manajerial yang maksimal diperlukan sistem pengendalian manajemen yang dapat dimanfaatkan untuk memotivasi seluruh personel perusahaan guna mewujudkan tujuan perusahaan melalui perilaku yang diharapkan. Sistem pengendalian manajemen ialah proses dan struktur yang tertata secara digunakan untuk mencapai tujuan perusahaan dengan strategi tertentu secara efisien. Unsur-unsur dari sistem pengendalian manajemen meliputi: perencanaan anggaran, alokasi sumber daya, pengukuran, evaluasi, penghargaan atas kinerja, pertanggungjawaban, dan penetapan harga transfer (Sulijaya \& Nuraini, 2015).

Menurut Narsa dan Yuniawati (2003) dalam Adang \& Hernawati (2013), menyatakan bahwa Kinerja Manajerial adalah kinerja para individu dalam kegiatan manajerial. Kinerja personel melputi 8 dimensi yaitu:

1) Perencanaan, perencanaan dalam arti kemampuan untuk menentukan tujuan, kebijakan dan tindakan/pelaksanaan, penjadwalan kerja, penganggaran, merancang prosedur, dan pemrograman.

2) Investigasi yaitu kemampuan mengumpulkan dan menyampaikan informasi untuk catatan, laporan, dan rekening, mengukur hasil, menentukan persediaan, dan analisis pekerjaan.

3) Pengkoordinasian yaitu kemampuan melakukan tukar menukar informasi dengan orang lain di bagian organisasi yang lain untuk mengkaitkan dan menyesuaikan program, memberitahu bagian lain, dan hubungan dengan manajer lain.

4) Evaluasi yaitu kemampuan untuk menilai dan mengukur proposal, kinerja yang diamati atau dilaporkan, penilaian pegawai, penilaian catatan hasil, penilaian laporan keuangan, pemeriksaan produk.

5) Pengawasan (supervisi) yaitu kemampuan untuk mengarahkan, memimpin dan mengembangkan bawahan, membimbing, melatih dan menjelaskan peraturan kerja pada bawahan, memberikan tugas pekerjaan dan menangani bawahan.

6) Pengaturan staff (staffing) yaitu kemampuan untuk mempertahankan angkatan kerja dibagian anda, merekrut, mewawancarai dan memilih pegawai baru, menempatkan, mempromosikan dan mutasi pegawai.

7) Negosiasi yaitu kemampuan dalam melakukan pembelian, penjualan atau melakukan kontrak untuk barang dan jasa, menghubungi pemasok, tawar menawar dengan wakil penjual, tawar-menawar secara kelompok.

8) Perwakilan (representatif) yaitu kemampuan dalam menghadiri pertemuanpertemuan dengan perusahaan lain, pertemuan perkumpulan bisnis, pidato untuk acara-acara kemasyarakatan, pendekatan kemasyarakatan, mempromosikan tujuan umum perusahaan. Tujuan utama penilaian 
kinerja dalah untuk memotivasi personil dalam mencapai sasaran organisasi dan dalam memahami standard.

Menurut Wibowo (2010), manajemen kinerja adalah manajemen tentang menciptakan hubungan dan memastikan komunikasi yang efektif. Manajemen kinerja memfokuskan pada apa yang diperlukan oleh organisasi, manajer dan pekerja untuk berhasil. Dapat ditarik kesimpulan Kinerja Manajerial adalah tentang bagaimana kinerja dikelola untuk memperoleh sukses. Kinerja berasal dari pengertian performance. Kinerja merupakan hasil pekerjaan yang mempunyai hubungan kuat dengan tujuan strategis organisasi, kepuasan konsumen dan memberikan kontribusi pada ekonomi. Dengan demikian, kinerja adalah tentang melakukan pekerjaan dan hasil yang dicapai dari pekerjaan tersebut. Kinerja adalah tentang apa yang dikerjakan dan bagaimana cara mengerjakannya.

\subsection{Kerangka Konseptual}

Kinerja manajerial merupakan salah satu faktor yang dapat meningkatkan efektivitas organsiasi. Menurut Mahoney, dkk (1963) dalam Devianti (2017), kinerja manajerial adalah kinerja individu anggota organisasi dalam kegiatan - kegiatan manajerial seperti perencanaan, investigasi, pengkoordinasian, evaluasi, pengawasan, pengaturan staf, negosiasi dan perwakilan.

Partisipasi anggaran merupakan keikutsertaan individu dalam menyusun anggaran sebagai proses pengambilan keputusan yang bermanfaat untuk mencapai tujuan organisasi. Partisipasi anggaran sebagai tingkat keterlibatan manajer dalam penyiapan anggaran dan pembuatan keputusan untuk mencapai tujuan.

Chenall dan Morris (1986) dalam Pratami (2015), mengungkapkan bahwa karakteristik sistem informasi akuntansi manajemen yang berupa broadscope, aggregation, integration dan timeliness mampu meningkatkan kinerja manajer. Manajer yang memiliki informasi dengan karakteristik tersebut umumnya mampu untuk membuat perencanaan yang lebih baik dan mencapai target yang telah ditetapkan.

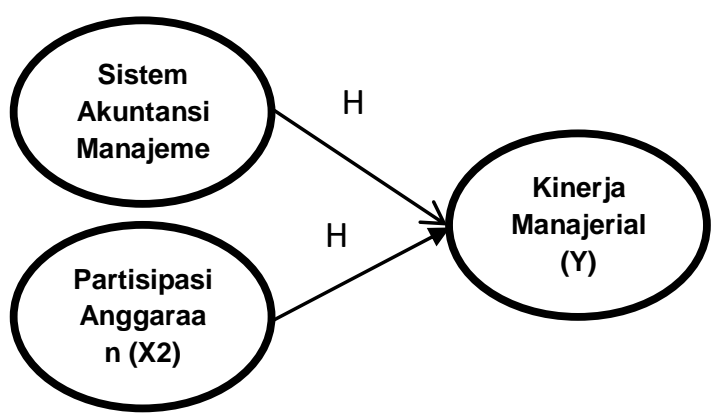

Gambar 1. Kerangka konseptual

\subsection{Hipotesis}

\section{a. Pengaruh Sistem Akuntansi Manajemen Terhadap Kinerja Manajerial}

Sistem akuntansi manajemen merupakan topik yang sangat menarik dalam penelitian bidang akuntansi khususnya akuntansi manajemen. Karakteristik sistem akuntansi manajemen menghasilkan informasi yang sangat berguna untuk membantu para manajer organisasi dalam pengambilan keputusan yang pada akhirnya dapat untuk lebih meningkatkan kinerja manajerialnya.

Mia dan Chanel dalam Sianipar (2018), mengemukakan bahwa jika para manajer menggunakan informasi yang disediakan oleh sistem akuntansi manajemen maka para manajer tersebut dapat melaksanakan hal yang lebih baik dalam melaksanakan pekerjaan dan 
perbaikan dalam kinerjanya. Faktorfaktor potensial yang dapat dijadikan sebagai dasar pemikiran untuk menghubungkan antara sistem akuntansi manajerial dengan kinerja manajerial adalah didasarkan pada kepercayaan bahwa para manajer memahami sifat pekerjanya. Dengan kata lain dengan memahami sifat pekerjaannya, maka mereka dapat mempertimbangkan bagaimana caranya menggunakan informasi agar lebih bermanfaat bagi merek dan melaksanakan pekerjaan dengan efektif. Diharapkan bahwa dengan menggunakan informasi yang disediakan, manajer dapat menyelesaikan pekerjaan secara efektif yang pada akhirnya dapat meningkatkan kinerja manajerial.

Penggunaan sistem akuntansi manajemen perusahaan akan mendapat informasi-informasi yang sangat penting. Sistem akuntansi manajemen juga dapat memuat informasi-informasi yang dapat dijadikan sebagai dasar untuk program promosi, untuk penjualan, untuk pajak, kategori pelanggan dan tingkat pelanggan. Hal tersebut juga dapat dijadikan sebagai salah satu rencana sarana untuk lebih meningkatkan pelayanan dan kualitas perusahaan itu sendiri. Selanjutnya para manajer yang dapat menggunakan sistem akuntansi manajemen dengan baik, sangat memungkinkan para manajer tersebut untuk melihat dan memastikan apakah perusahaan mereka bersaing dengan perusahaan-perusahaan pesaing mereka, dalam penawaran produk dan pelayanan untuk konsumen berupa harga yang kompetitif, pelayanan dan fasilitas yang mereka punya untuk konsumen.

Hasil penelitian Sulani (2013), Wulandari, dkk (2014), Lempas,dkk (2014), Rante, dkk (2014), Lempas
(2014), Eliana, dkk (2014), Pratami (2015), Syafira (2015), Damayanti, dkk (2015), Solikah (2017), dan Qibtiyah (2018) menemukan bahwa sistem akuntansi manajemen berpengaruh positif dan signifikan terhadap kinerja manajerial. Dengan demikian maka hipotesis pertama (H1) yang diajukan dalam penelitian ini adalah sebagai berikut:

\section{H1: Sistem Akuntansi Manajemen berpengaruh positif dan signifikan terhadap kinerja manajerial}

\section{b. Pengaruh Partisipasi Anggaran Terhadap Kinerja Manajerial}

Hubungan pertama di dalam expectancy theory yang dikemukakan oleh Vroom adalah hubungan antara upaya dan kinerja (effortperformance/E-P), dalam hal ini pegawai cenderung akan bekerja lebih giat bila memiliki keyakinan bahwa usahanya tersebut akan menghasilkan penilaian kinerja yang lebih baik (Robbins dan Judge, 2015). Salah satu bentuk pengaplikasian hubungan upaya dan kinerja adalah dengan melibatkan manajer di dalam penyusunan anggaran dan kemudian dijadikan salah satu dasar penilaian kinerja.

Sedangkan menurut goal-setting theory individu akan lebih berkomitmen untuk melaksanakan tujuannya terjadi ketika individu tersebut menetapkan tujuannya sendiri dan bukan diberikan dan ketika tujuan tersebut didasarkan pada setidaknya sebagian dari kemampuan individu (Colbert, 2005 dalam Wibowo, 2017). Dengan kata lain dengan memberikan kesempatan kepada pegawainya untuk dapat menetapkan tujuannya cenderung untuk bekerja lebih 
baik bila dibandingkan ketika tujuan hanya ditetapkan oleh atasan saja.

Menurut Hansen dan Mowen (2006) dan Wibowo (2017), partisipasi anggaran bila tidak dilaksanakan dengan benar dapat mengakibatkan kegagalan dalam mencapai standar dan akan membuat frustasi bagi para manajer bila diterapkan terlalu ketat, namun bila terlalu mudah dicapai maka akan membuat manajer kehilangan minat dalam bekerja. Akibat lainnya dari penerapan partisipasi anggaran yang kurang benar adalah dapat menyebabkan kesenjangan dalam anggaran dan munculnya partisipasi semu.

Hasil penelitian Amartadewi (2013), Hanny (2013), Kamilah (2013), Lina dan Stella (2013), Minai and Mun (2013), Kholidah (2014), Putri (2014), Putri dan Adiguna (2014), Tapatfeto (2014), Moheri (2015), Gunawan (2015), Windasari (2016), Asmas (2016), Devianti (2017), Giusti, dkk (2018), Rachmaningtyas, dkk (2018), Pratiwi (2019) dan Iswahyudi (2019), menemukan bahwa partisipasi anggaran memiliki hubungan positif pada kinerja manajerial. Dengan demikian maka hipotesis kedua (H2) yang diajukan dalam penelitian ini adalah sebagai berikut:

\section{H2: Partisipasi berpengaruh positif dan signifikan terhadap kinerja manajerial}

\section{METODE PENELITIAN}

\subsection{Metode Analisis Data}

\section{a. Analisis Deskriptif}

Analisis deskriptif adalah suatu metode analisis dimana data-data dikumpulkan, diklarifikasikan, dikelompokkan, selanjutnya dianalisis dan diinterpretasikan secara objektif dalam rangka menerangkan objek tertentu. Penelitian ini menggunakan analisis deskriptif untuk membantu menerangkan hasil temuan penelitian.

\section{b. Uji Instrumen Penelitian}

\section{1) Uji Validitas}

Validitas adalah skala dimana kesimpulan yang dibuat dengan berdasarkan skor menurut angka menjadi sesuai. Pengujian validitas ini menggunakan Total Correlation (Corrected Item), analisis ini dengan caramengkolerasikan masing-masing skor item dengan skor total dan melakukan koreksi terhadap nilai koefisien korelasi yang overestimasi. Pengujian menggunakan dua sisi dengan taraf signifikasi 0,05.

\section{2) Uji Reliabilitas}

Pengujian ini menggunakan metode statistik Cronbach Alpha dengan nilai sebesar 0,06. Apabila Cronbach Alpha dari suatu variabel $\geq 0,6$ maka butir pertanyaan dalam instrumen penelitian tersebut adalah reliabel atau dapat diandalkan, dan sebaliknya jika nilai Cronbach Alpha $<0<6$ maka butir pertanyaan tersebut tidak reliabel.

\section{c. Uji Asumsi Klasik}

Uji asumsi klasik digunakan untuk mengetahui apakah hasil analisis regresi linier berganda yang digunakan untuk menganalisis dalam penelitian ini terbebas dari penyimpangan asumsi klasik. Uji asumsi klasik yang digunakan dalam penelitian ini meliputi uji normalitas, multikolinieritas, dan heteroskedastisitas. Adapun masingmasing pengujian tersebut dapat dijabarkan secara ringkas sebagai berikut: 


\section{1) Uji Normalitas}

Uji normalitas bertujuan untuk menguji apakah dalam suatu model regresi linier variabel terikat dan variabel bebas keduanya mempunyai distribusi normal atau tidak (Ghozali, 2015). Setiap penelitian mengharuskan normalitas data dengan kata lain model regresi yang baik tercermin dari distribusi data normal. Penelitian ini, untuk mendeteksi normalitas data dapat dilakukan dengan pengujian berikut:

a) Histogram

Pengujian dengan model histogram memiliki ketentuan bahwa data normal berbentuk lonceng. Data yang baik adalah data yang memiliki pola distribusi normal. Jika data melenceng ke kanan atau melenceng ke kiri berarti data tidak terdistribusi secara normal.

b) Grafik Normality Probability Plot

Dalam uji ini, ketentuan yang digunakan adalah:

- Jika data menyebar di sekitar garis diagonal dan mengikuti arah garis diagonal, maka model regresi memenuhi asumsi normalitas; dan

- Jika data menyebar jauh dari diagonal dan/atau tidak mengikuti arah garis diagonal, maka model regresi tidak memenuhi asumsi normalitas.

\section{2) Uji Multikolinearitas}

Uji multikolinieritas bertujuan untuk menguji apakah model regresi mempunyai korelasi antara variabel bebas, dengan kata lainModel regresi yang baik seharusnya tidak terjadi korelasi diantara variabel independen. Dalam hal ini disebut variabel-variabel bebas ini tidak ortogonal.

Dalam mendeteksi ada tidaknya multikolinearitas di dalam model regresi salah satunya dilihat dari: (1) nilai tolerance dan lawannya; dan (2) variance inflation factor (VIF). Kedua ukuran ini menunjukan setiap variabel independen manakah yang dijelaskan oleh variabel independen lainnya. Nilai cut off yang umum dipakai untuk menunjukan adanya multikolinearitas adalah nilai tolerance $<0.10$ atau sama dengan nilai VIF > 10 (Ghozali, 2015).

\section{3) Uji Heteroskedastisitas}

Uji heteroskedastisitas bertujuan menguji model regresi, apakah terdapat ketidaksamaan variance dari residual satu pengamatan ke pengamatan lain. Konsekuensinya adanya heteroskedastisitas dalam model regresi adalah penaksir yang diperoleh tidak efisien, baik dalam sampel kecil maupun besar. Salah satu cara yang dapat digunakan untuk mengetahui ada tidaknya gejala heteroskedastisitas adalah dengan melihat pada grafik scatter plot. Jika ada pola tertentu seperti titik-titik yang membentuk pola tertentu yang teratur (bergelombang, melebar, kemudian menyempit) maka mengindikasikan telah terjadi heteroskedastisitas. Jika tak ada pola yang jelas maka tidak terjadi gejala heteroskedastisitas.

\section{d. Uji Hipotesis}

\section{1) Analisis Regresi Linear Berganda}

Analisis regresi linear berganda digunakan untuk mengetahui pengaruh antara variabel bebas terhadap variabel terikat. Persamaan regresi linear berganda yaitu:

$$
\mathrm{Y}=\boldsymbol{\beta}_{0}+\boldsymbol{\beta} 1 \mathrm{X} 1+\boldsymbol{\beta} 2 \mathrm{X} 2+\mathrm{e}
$$

Keterangan:

$\begin{array}{ll} & =\text { Kinerja Manajerial } \\ \beta_{0} & =\text { Nilai Konstan } \\ \mathrm{X} 1 & =\text { Sistem Akuntansi Manajemen } \\ \mathrm{X} 2 & =\text { Partisipasi Anggaran } \\ \beta_{1}, \beta_{2} & =\text { Koefisien Korelasi } \\ \mathrm{e} & =\text { Standar error }\end{array}$




\section{2) Uji parsial (uji t)}

Penelitian ini menggunakan uji thitung bertujuan untuk melihat secara parsial apakah ada pengaruh dari variabel bebas terhadap variabel terikat. Penelitian ini akan menggunakan uji $\mathrm{t}$ untuk menguji hipotesis $\mathrm{HO}$ atau hipotesis $\mathrm{H} 1$ yang telah diajukan dengan melihat signifikansi pada masing-masing t hitung. Jika nilai signifikan lebih kecil dari 0,05 atau $5 \%$ maka hipotesis yang diajukan diterima atau dikatakan signifikan, sedangkan jika nilai signifikan lebih besar dari 0,05 atau 5\% maka hipotesis yang diajukan ditolak atau dikatakan tidak signifikan.

\section{3) Pengujian Koefisien Determinan $\left(R^{2}\right)$}

Uji Determinan membantu melihat seberapa besar kontribusi variabel bebas terhadap variabel terikat. Dengan kata lain koefisien determinan digunakan untuk mengukur besarnya pengaruh variabel bebas yang diteliti terhadap

Tabel 10

Uji Validitas

\begin{tabular}{|c|c|c|c|}
\hline Variabel & Pertanyaan & $\mathbf{r}_{\text {hitung }}>\mathbf{r}_{\text {tabel }}$ & Keterangan \\
\hline \multirow{2}{*}{$\begin{array}{c}\text { Sistem Akuntansi } \\
\text { Manajemen (X1) }\end{array}$} & $\mathrm{X} 11$ & $0,798>0,286$ & Valid \\
\cline { 2 - 4 } & $\mathrm{X} 12$ & $0,857>0,286$ & Valid \\
\cline { 2 - 4 } & $\mathrm{X} 13$ & $0,838>0,286$ & Valid \\
\cline { 2 - 4 } & $\mathrm{X} 14$ & $0,857>0,286$ & Valid \\
\hline \multirow{4}{*}{$\begin{array}{c}\text { Partisipasi } \\
\text { Anggaran (X2) }\end{array}$} & $\mathrm{X} 41$ & $0,829>0,286$ & Valid \\
\cline { 2 - 4 } & $\mathrm{X} 42$ & $0,672>0,286$ & Valid \\
\cline { 2 - 4 } & $\mathrm{X} 43$ & $0,605>0,286$ & Valid \\
\cline { 2 - 4 } & $\mathrm{X} 44$ & $0,657>0,286$ & Valid \\
\hline \multirow{2}{*}{ Kinerja Manajerial } & $\mathrm{Y} 1$ & $0,922>0,286$ & Valid \\
\cline { 2 - 4 }$(\mathrm{Y})$ & $\mathrm{Y} 2$ & $0,789>0,286$ & Valid \\
\cline { 2 - 4 } & $\mathrm{Y} 3$ & $0,808>0,286$ & Valid \\
\cline { 2 - 4 } & $\mathrm{Y} 4$ & $0,752>0,286$ & Valid \\
\cline { 2 - 4 } & $\mathrm{Y} 5$ & $0,719>0,286$ & Valid \\
\hline
\end{tabular}

Sumber: Data primer diolah, 2020

Hasil uji validitas menunjukkan bahwa semua item pertanyaan dalam dalam kuesioner adalah valid dan dapat variabel terikat. Koefisien determinan $\left(R^{2}\right)$ berkisar antara nol sampai dengan satu $\left(0 \leq R^{2} \leq 1\right)$. Hal ini berarti $R^{2}=0$ menunjukkan tidak adanya pengaruh variabel bebas terhadap variabel terikat.

\section{HASIL DAN PEMBAHASAN}

\subsection{Hasil Penelitian}

\section{a. Uji Validitas}

Pengujian validitas menunjukkan ketelitian serta ketepatan kuesioner yang dibagikan kepada responden. Untuk mengetahui validitas pertanyaan dari setiap variabel, maka rhitung dibandingkan dengan r-tabel. r-tabel dapat dihitung dengan $\mathrm{df}=\mathrm{N}-2$. Jumlah responden dalam penelitian ini sebanyak 34 , sehingga $d f=34-2=32, r(?: 32)=$ 0,286. Jika r-hitung> r-tabel, maka pertanyaan tersebut dikatakan valid. 


\section{b. Uji Reliabilitas}

\section{Pengujian}

reliabilitas

menunjukkan seberapa besar suatu instrument tersebut dapat dipercaya dan digunakan sebagai alat pengumpul data. Reliabilitas instrumen yang semakin tinggi, menunjukkan hasil ukur yang didapatkan semakin terpercaya (reliabel). Penentuan reabilitas instrumen suatu penelitian adalah:

1) Jika cronbach's alpha $<0,6$ maka reabiliti dikatakan buruk;

2) Jika cronbach's alpha 0,6 - 0,8 maka reabiliti dikatakan cukup; dan

3) Jika cronbach's alpha $>0,8$ maka reabiliti dikatakan baik.

Berikut adalah hasil uji reliabilitas atas variable - variabel:

Tabel 11

Uji Reliabilitas

\begin{tabular}{|l|c|c|}
\hline Variabel & $\begin{array}{c}\text { Koefisien } \\
\text { Alpha }\end{array}$ & Keterangan \\
\hline $\begin{array}{l}\text { Sistem } \\
\text { Akuntansi } \\
\text { Manajemen }\end{array}$ & 0,856 & Baik \\
\hline $\begin{array}{l}\text { Partisipasi } \\
\text { Anggaran }\end{array}$ & 0,628 & Cukup \\
\hline $\begin{array}{l}\text { Kinerja } \\
\text { Manajerial }\end{array}$ & 0,855 & Baik \\
\hline
\end{tabular}

Sumber: Data primer diolah, 2020

Berdasarkan hasil pengujian reliabilitas, menunjukkan bahwa semua variabel yang dijadikan instrumen dalam penelitian adalah reliabel dan dapat digunakan sebagai alat pengumpulan data. Sehingga berdasarkan hasil uji reliabilitas diatas, menunjukkan bahwa instrument memiliki tingkat reliabilitas yang tinggi, hal ini dibuktikan dengan nilai koefisien alpha>0,60, jadi hasil ukur yang akan didapatkan dapat dipercaya.

\section{c. Uji Asumsi Klasik}

1) Uji Normalitas

Uji normalitas dilakukan untuk melihat apakah dalam model regresi variabel terikat dan variabel bebas keduanya mempunyai distribusi normal atau tidak. Model regresi yang baik adalah model regresi yang berdistribusi normal. Cara mendeteksi normalitas dilakukan dengan melihat grafik histogram.

\section{Gambar 2}

\section{Grafik Histogram}

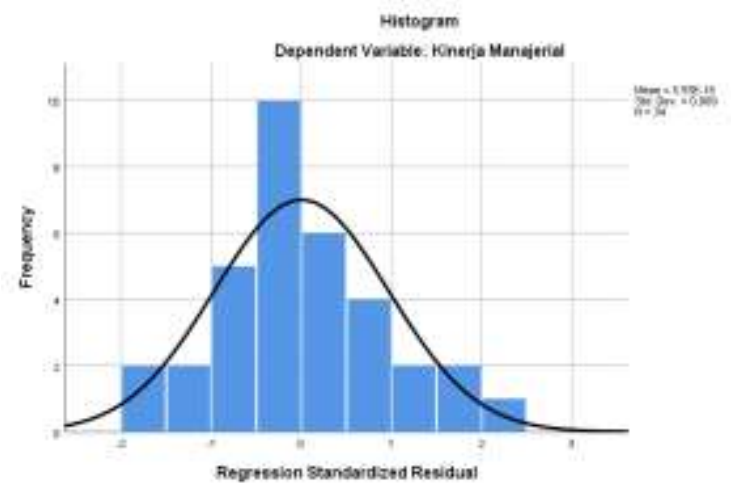

Sumber: Output SPSS, 2020

Berdasarkan grafik histogram diatas, dapat disimpulkan bahwa grafik histogram memberikan pola distribusi yang mendekati normal, hal ini dibuktikan dengan melihat bahwa grafik membentuk simetris dan mengikuti garis diagonal. Akan tetapi grafik histogram ini hasilnya tidak terlalu akurat apalagi ketika jumlah sampel yang digunakan kecil.

Metode yang handal adalah dengan melihat normal probability plot. Pada grafik normal plot terlihat titik-titik menyebar disekitar garis diagonal serta penyebarannya mengikuti arah garis diagonal. 


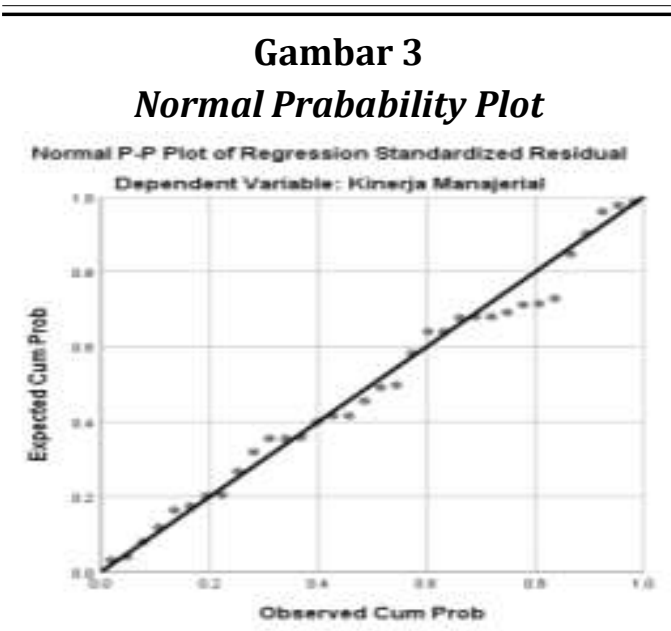

Sumber: Output SPSS, 2020

Berdasarkan grafik normal probability plot, dapat dilihat bahwa titik menyebar disekitar garis diagonal dan penyebarannya mengikuti garis diagonal, sehingga dapat dikatakan bahwa pola distribusinya normal. Melihat kedua grafik diatas, dapat disimpulkan bahwa model regresi dalam penelitian ini dapat digunakan karena memenuhi asumsi normalitas.

\section{d. Uji Heteroskedastisitas}

Heteroskedastisitas menunjukkan bahwa variansi variabel tidak sama untuk semua pengamatan. Jika variansi dari residual satu pengamatan ke pengamatan yang lain tetap, maka disebut homoskedastisitas. Model regresi yang baik adalah yang homoskedastisitas atau tidak terjadi heteroskedastisitas karena data cross section memiliki data yang mewakili berbagai ukuran (kecil, sedang, dan besar). Untuk mendeteksi adanya Heteroskedastisitas, metode yang digunakan adalah metode chart (diagram Scatterplot). Jika:

1) Jika ada pola tertentu terdaftar titiktitik, yang ada membentuk suatu pola tertentu yang beraturan (bergelombang, melebar, kemudian menyempit), maka terjadi Heteroskedastisitas.
2) Jika ada pola yang jelas, serta titiktitik menyebar keatas dan dibawah 0 pada sumbu Y, maka tidak terjadi Heteroskedastisitas.

\section{Gambar 4} Diagram Scatterplot

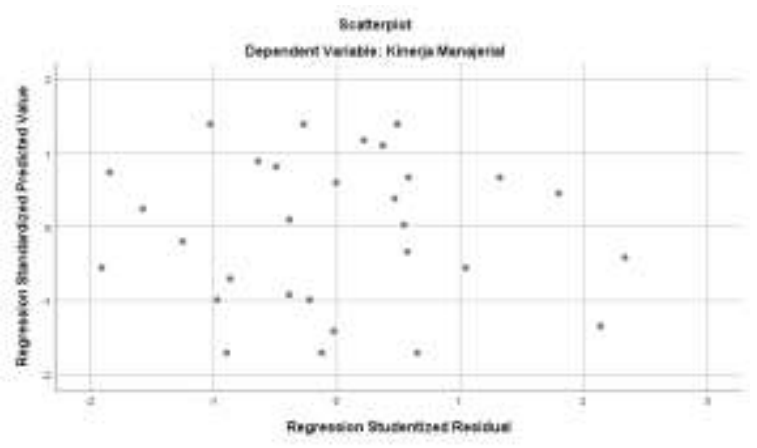

Sumber: Output SPSS, 2020

Berdasarkan diagram diatas, maka dapat dilihat bahwa data tersebar secara acak dan tidak membentuk suatu pola tertentu, hal ini menunjukkan bahwa tidak terdapat heteroskedastisitas. Dengan demikian dapat disimpulkan bahwa terjadinya perbedaan varians dari residual dari suatu pengamatan ke pengamatan yang lain.

\section{e. Uji Multikolinearitas}

Uji Multikolinearitas bertujuan menguji adanya korelasi antara variabel bebas (independent) pada model regresi. Pada model regresi yang baik seharusnya tidak terjadi korelasi diantara variabel. Untuk menguji ada atau tidaknya multikolinearitas dalam model regresi dapat dilihat dari nilai tolerance dan lawannya, yaitu dengan melihat variance inflation factor (VIF). Nilai cut-off yang umum dipakai adalah nilai tolerance 0,01 . Salah satu cara untuk menguji adanya multikoloniearitas dapat dilihat dari Variance Inflation Factor (VIF). Jika nilai $\quad \mathrm{VIF}>10$ maka terjadi multikolinearitas. 
Tabel 12

Uji Multikolinearitas

\begin{tabular}{|l|c|c|}
\hline \multicolumn{1}{|c|}{ Variabel } & VIF & Keterangan \\
\hline Sistem Akuntansi Manajemen & 1,370 & Tidak Multikolinearitas \\
\hline Partisipasi Anggaran & 1,370 & Tidak Multikolinearitas \\
\hline
\end{tabular}

Sumber: Output SPSS, 2020

Berdasarkan tabel di atass, dapat disimpulkan bahwa model regresi untuk variabel independen yang diajukan oleh peneliti untuk diteliti bebas dari multikolinearitas. Hal ini dapat dibuktikan dengan melihat table diatas yang menunjukkan nilai VIF dari masingmasing variabel independen $<10$, dan dapat digunakan untuk mengetahui pengaruh pengintegrasian terhadap kinerja manajerial.
Uji regresi linear berganda dilakukan untuk mengetahui hubungan fungsional antara variabel bebas (independent) terhadap varaiabel terikat (dependent). Hasil uji regresi linear berganda dapat dilihat dari persamaan berikut. Penelitian ini menguji pengaruh kualitas pengelola keuangan dan sistem pengendalian intern pemerintah terhadap efektifitas pengelolaan keuangan daerah.

\section{e. Analisis Regresi Linear Berganda}

Tabel 13

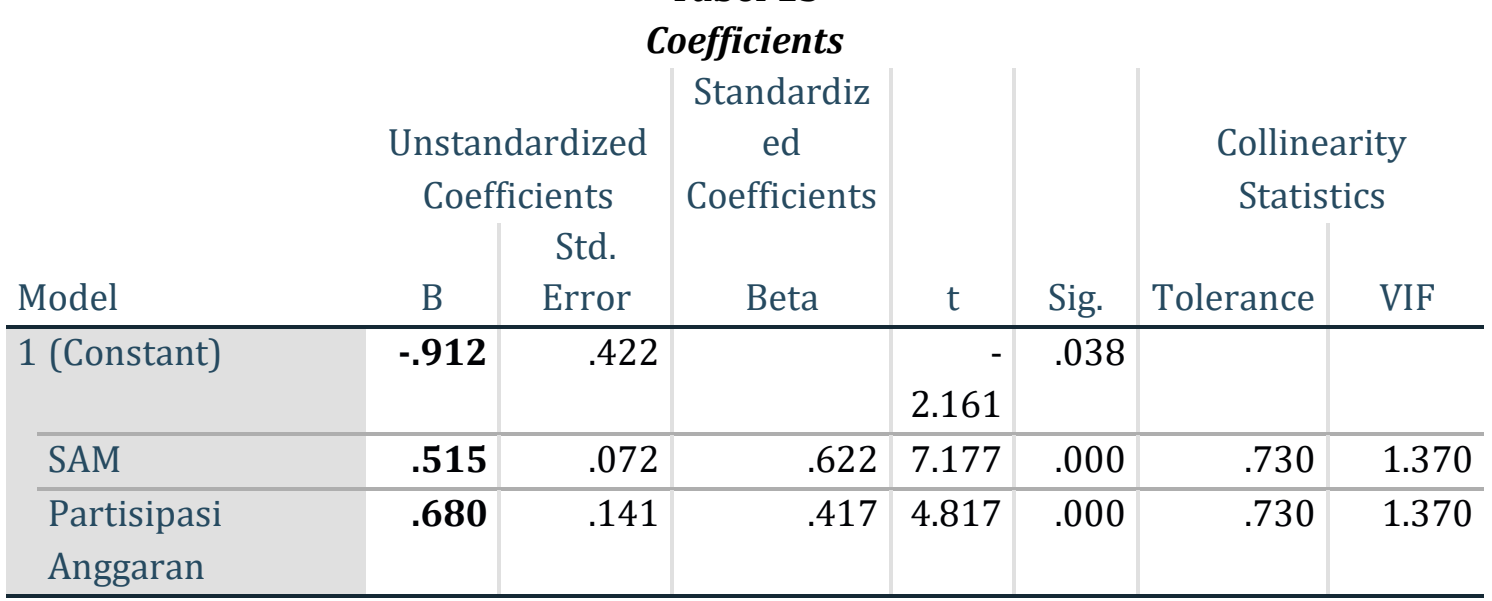

Sumber: Output SPSS, 2020

Berdasarkan tabel Coefficients hasil output SPSS di atas maka diketahui persamaan regresi sebagai berikut:

$$
Y=-0,912+0,515 X_{1}+0,680 X_{2}
$$

Dalam persamaan regresi linear berganda di atas dapat dijelaskan secara rinci:

\section{1) Konstanta $(\alpha)$}

Konstanta sebesar $-0,912$. Hal ini berarti jika tidak ada perubahan dari variabel sistem akuntansi manajemen dan partisipasi anggaran, maka kinerja manajerial akan menurun sebesar 0,912.

2) Sistem Akuntansi Manajemen (X1)

Nilai koefisien regresi untuk sistem akuntansi manajemen sebesar 0,515. Dalam penelitian ini dapat dinyatakan bahwa sistem akuntansi manajemen berpengaruh positif terhadap kinerja manajerial. Setiap peningkatan sistem akuntansi manajemen akan memberikan dampak pada meningkatnya kinerja manajerial sebesar 0,515. 
3) Partisipasi Anggaran (X2)

Nilai koefisien regresi untuk partisipasi anggaran sebesar 0,680. Dalam penelitian ini dapat dinyatakan bahwa partisipasi berpengaruh positif terhadap kinerja manajerial. Setiap peningkatan partisipasi anggaran akan memberikan dampak pada meningkatnya kinerja manajerial sebesar 0,680 .

\section{f. Uji Parsial (Uji t)}

Uji parsial digunakan untuk mengetahui apakah variabel independet (X) berpengaruh signifikan terhadap variabel dependen (Y). Pengujian dilakukan dengan taraf signifikansi 0,05. Jika Sig>0,05 maka hipotesis yang diajukan ditolak. Sebaliknya Jika Sig.< 0,05 maka hipotesis yang diajukan diterima.

Tabel 14

Uji t

\begin{tabular}{|l|c|c|c|}
\hline \multicolumn{1}{|c|}{ Varibel } & Sig. $<\boldsymbol{\alpha}$ & Keterangan & Hipotesis \\
\hline Sistem Akuntansi Manajemen & $0,000<0,05$ & Signifikan & Diterima \\
\hline Partisipasi Anggaran & $0,000<0,05$ & Signifikan & Diterima \\
\hline
\end{tabular}

Sumber: Output SPSS, 2020

Berdasarkan hasil uji parsial telah dilakukan diketahui bahwa sistem akuntansi manajemen (X1) dan partisipasi anggaran motivasi (X2) masing - masing secara parsial memiliki pengaruh yang signifikan terhadap kinerja manajerial.

\section{g. Uji Simultan (Uji F)}

\begin{tabular}{|c|c|c|c|c|c|}
\hline \multicolumn{6}{|c|}{ Uji F } \\
\hline Model & $\begin{array}{c}\text { Sum of } \\
\text { Squares }\end{array}$ & $\mathrm{df}$ & $\begin{array}{l}\text { Mean } \\
\text { Square }\end{array}$ & $\mathrm{F}$ & Sig. \\
\hline $\begin{array}{c}1 \text { Regressio } \\
\mathrm{n}\end{array}$ & 11.628 & 2 & 5.814 & $\begin{array}{r}75.81 \\
5\end{array}$ & $.000^{b}$ \\
\hline Residual & 2.377 & 31 & .077 & & \\
\hline Total & 14.005 & 33 & & & \\
\hline
\end{tabular}

Sumber: Output SPSS, 2020

Berdasarkan hasil uji simultan yang telah dilakukan antara variabel sistem akuntansi manajeman dan partisipasi anggaran terhadap kinerja manajerial diketahui bahwa nilai Sig. adalah sebesar 0,000. Nilai tersebut lebih kecil dari derajat kesalahan $(\alpha=0,05)$ $(0,00<0,05)$. Dengan kata lain, variabel sistem akuntansi manajeman dan partisipasi anggaran secara simultan

Tabel 15
Uji F digunakan untuk mengetahui pengaruh simultan dari semua variabel independet (X) terhadap variabel dependen (Y). Pengujian dilakukan dengan taraf signifikansi 0,05. Jika Sig.>0,05 maka hipotesis yang diajukan ditolak. Sebaliknya Jika Sig.<0,05 maka hipotesis yang diajukan diterima. 
Tabel 16

Uji Determinasi

\begin{tabular}{cc|c|c|c} 
Model & $\mathrm{R}$ & R Square & $\begin{array}{c}\text { Adjusted R } \\
\text { Square }\end{array}$ & $\begin{array}{c}\text { Std. Error of } \\
\text { the Estimate }\end{array}$ \\
\hline 1 & $.911^{\mathrm{a}}$ & .830 & .819 & .27692 \\
\hline \multicolumn{2}{l}{ Sumber: Output SPSS, 2020}
\end{tabular}

Berdasarkan hasil uji koefisien deteminasi di atas, diketahui bahwa kinerja manajerial mampu dijelaskan oleh variabel sistem akuntansi manajeman dan partisipasi anggaran sebesar $83,0 \%$. Sisanya $17,0 \%$ dari kinerja manajerial dijelaskan oleh variabel lain yang tidak disertakan dalam penelitian.

\subsection{Pembahasan}

\section{a. Pengaruh Sistem Akuntansi Manajemen terhadap Kinerja Manajerial}

Sistem akuntansi manajemen merupakan instrumen yang digunakan untuk mengukur tingkat keandalan informasi akuntansi manajemen. Instrumen yang digunakan untuk mengukur tingkat keandalan informasi akuntansi manajemen dibagi menjadi empat. Keempat indikator diadopsi dari peneliti terdahulu (Sianipar, 2018).

Berdasarkan hasil penelitian diketahui bahwa sistem akuntansi manajemen memiliki pengaruh positif terhadap kinerja manajerial. Hal ini berarti bahwa penerapan sistem akuntansi manajemen memiliki pengaruh searah terhadap kinerja manajerial. Peningkatan sistem akuntansi manajemen akan memberikan dampak pada meningkatnya kinerja manajerial.

Sementara itu, berdasarkan uji parsial diketahui bahwa sistem akuntansi manajemen memiliki pengaruh yang signifikan terhadap kinerja manajerial. Hal ini berarti bahwa sistem akuntansi manajemen merupakan faktor penentu baik dan tidaknya kinerja manajerial pada lingkup SKPD di kabupaten Sidrap. Hasil penelitian ini sejalan dengan teori yang dikemukakan Mia dan Chanel dalam Sianipar (2018), bahwa jika para manajer menggunakan informasi yang disediakan oleh sistem akuntansi manajemen maka para manajer tersebut dapat melaksanakan hal yang lebih baik dalam melaksanakan pekerjaan dan perbaikan dalam kinerjanya.

Hasil penelitian ini sejalan dengan hasil penelitian sebelumnya dari Sulani (2013), Wulandari, dkk (2014), Lempas,dkk (2014), Rante, dkk (2014), Lempas (2014), Eliana, dkk (2014), Pratami (2015), Syafira (2015), Damayanti, dkk (2015), Solikah (2017), dan Qibtiyah (2018) yang menemukan bahwa sistem akuntansi manajemen berpengaruh positif dan signifikan terhadap kinerja manajerial.

\section{b. Pengaruh Partisipasi Anggaran terhadap Kinerja Manajeria}

Partisipasi anggaran merujuk pada pengaruh tingkat keterlibatan yang dirasakan oleh individu di dalam proses penyusunan anggaran. Partisipasi dalam penyusunan anggaran dalam penelitian ini berkaitan dengan seberapa jauh keterlibatan pejabat struktural dalam menentukan dan menyusun anggaran di masing-masing unit organisasinya.

Berdasarkan hasil penelitian diketahui bahwa partisipasi anggaran memiliki pengaruh positif terhadap 
kinerja manajerial. Hal ini berarti bahwa penerapan partisipasi anggaran memiliki pengaruh searah terhadap kinerja manajerial. Peningkatan partisipasi anggaran akan memberikan dampak pada meningkatnya kinerja manajerial.

Sementara itu, berdasarkan uji parsial diketahui bahwa partisipasi anggaran memiliki pengaruh yang signifikan terhadap kinerja manajerial. Hal ini berarti bahwa partisipasi anggaran merupakan faktor penentu baik dan tidaknya kinerja manajerial pada lingkup SKPD di kabupaten Sidrap. Hasil penelitian ini terdukung oleh Expectancy theory yang dikemukakan oleh Vroom bahwa pegawai cenderung akan bekerja lebih giat bila memiliki keyakinan bahwa usahanya tersebut akan menghasilkan penilaian kinerja yang lebih baik (Robbins dan Judge, 2015). Salah satu bentuk pengaplikasian hubungan upaya dan kinerja adalah dengan melibatkan manajer di dalam penyusunan anggaran dan kemudian dijadikan salah satu dasar penilaian kinerja.

Selain itu, hasil penelitian ini terdukung juga oleh goal - setting theory, di mana individu akan lebih berkomitmen untuk melaksanakan tujuannya terjadi ketika individu tersebut menetapkan tujuannya sendiri dan bukan diberikan dan ketika tujuan tersebut didasarkan pada setidaknya sebagian dari kemampuan individu (Colbert, 2005 dalam Wibowo, 2017). Dengan kata lain dengan memberikan kesempatan kepada pegawainya untuk dapat menetapkan tujuannya cenderung untuk bekerja lebih baik bila dibandingkan ketika tujuan hanya ditetapkan oleh atasan saja.

Menurut Hansen dan Mowen (2006) dan Wibowo (2017), partisipasi anggaran bila tidak dilaksanakan dengan benar dapat mengakibatkan kegagalan dalam mencapai standar dan akan membuat frustasi bagi para manajer bila diterapkan terlalu ketat, namun bila terlalu mudah dicapai maka akan membuat manajer kehilangan minat dalam bekerja. Akibat lainnya dari penerapan partisipasi anggaran yang kurang benar adalah dapat menyebabkan kesenjangan dalam anggaran dan munculnya partisipasi semu.

Hasil penelitian ini sejalan dengan hasil penelitian sebelumnya dari Hasil penelitian Amartadewi (2013), Hanny (2013), Kamilah (2013), Lina dan Stella (2013), Minai and Mun (2013), Kholidah (2014), Putri (2014), Putri dan Adiguna (2014), Tapatfeto (2014), Moheri (2015), Gunawan (2015), Windasari (2016), Asmas (2016), Devianti (2017), Giusti, dkk (2018), Rachmaningtyas, dkk (2018), Pratiwi (2019) dan Iswahyudi (2019), yang menemukan bahwa partisipasi anggaran memiliki hubungan positif pada kinerja manajerial.

\section{PENUTUP}

\subsection{Simpulan}

Berdasarkan hasil penelitian dan pembahasan pada bab sebelumnya maka simpulan penelitian ini adalah sebagai berikut:

1. Sistem Akuntansi Manajemen berpengaruh positif dan signifikan terhadap kinerja manajerial SKPD di Kabupaten Sidrap.

2. Partisipasi anggaran berpengaruh positif dan signifikan terhadap kinerja manajerial SKPD di Kabupaten Sidrap 


\subsection{Saran}

Berdasarkan simpulan penelitian maka saran yang diberikan dari penelitian ini adalah sebagai berikut:

1. Kepada Pemerintah Daerah Kabupaten Sidrap diharapkan untuk dapat mempertahankan penerapan sistem akuntansi manajemen dan partisipasi anggarannya karena telah terbukti mampu untuk meningkatkan kinerja pejabat strukturalnya.

2. Kepada peneliti selanjutnya agar menambah atau mengganti variable lainnya yang berhubungan dengan kinerja manjerial seperti sikap atasan, budaya organisasi dan aspek religiusitas. Selain itu agar dapat melakukan penelitian sejenis pada SKPD di pemerintah daerah lainnya sehingga hasil penelitian bisa digeneralisir.

\section{Daftar Pustaka}

Adang, Y. S. P. dan Hernawati, E. 2013. Pengaruh Sistem Pengukuran Kinerja Total Quality Management dan Sistem Penghargaan terhadap Kinerja Manajerial. Jurnal Universitas Pembangunan Nasional Veteran Jakarta.

Amartadewi, Tjokorda Istri Mas. 2013. Pengaruh Partisipasi Anggaran Terhadap Kinerja Manajerial Dengan Gaya Kepemimpinan Dan Locus Of Control Sebagai Variabel Moderasi. E-Jurnal Akuntansi Universitas Udayana 4.3 (2013): 550-566

Aprilianisa, Ranti Nur. 2018. Pengaruh Partisipasi Anggaran Dan Komitmen Organisasi Terhadap Kinerja Manajerial (Survey pada Pusat Mata Nasional Rumah Sakit Mata Cicendo Bandung). Skripsi, Perpustakaan Fakultas Ekonomi dan Bisnis Unpas Bandung.
Arsanti, Tutuk. 2009. Hubungan antara Penetapan Tujuan, Self Efficacy dan Kinerja. Jurnal Bisnis dan Ekonomi. Vol. 16, No. 2, ISSN: 1412-3126.

Asmas, Denny. 2016. Pengaruh Hubungan Partisipasi Anggaran Terhadap Kinerja Manajerial Dengan Komitmen Organisasi Sebagai Variabel Intervening (Studi Empiris Pada Manulife Financial Indonesia). Jurnal Ilmiah Universitas Batanghari Jambi, Vol. 16, No. 3.

Andison, Yvone Augustine. 2017. Partisipasi Anggaran, Kepuasan Kerja, dan Kinerja Manajerial: Studi pada Bisnis Keluarga Pempek di Kota Palembang. Esensi: Jurnal Bisnis dan Manajemen Volume 7 (1), April 2017 P-ISSN: 2087-2038; E-ISSN: 2461-1182 Halaman 73 82

Ayu, Gusti, dan Lovelly Dwinda Dahen. 2014. Pengaruh Karakteristik Informasi Sistem Akuntansi Manajemen terhadap Kinerja Manajerial Studi Empiris pada PT Bank Perkreditan Rakyat di Kabupaten Tanah Datar. ISSN: 2302-1590. E-ISSN: 2460-1900. Journal of Economic and Economic Education. Volume 3. Nomor 1, 9499.

Basri. 2011. Pengaruh Partisipasi Anggaran Terhadap Senjangan Anggaran Dengan Informasi Asimetri Sebagai Variabel Moderasi. Skripsi tidak diterbitkan. Makassar: Program Sarjana Universitas Hasanuddin

Damayanti, P. E., Sujana, E., \& Werastuti, D. N. S. 2015. Pengaruh Karakteristik Informasi Sistem Akuntansi Manajemen (SAM), Desentralisasi, dan Ketidakpastian Lingkungan Terhadap Kinerja Manajerial (Studi Empiris Pada Hotel Se-Kabupaten Buleleng). EJournal S1 AK UPG, 3 No. 1. 
Devianti, Heny. 2017. Pengaruh Partisipasi Anggaran Terhadap Kinerja Manajerial Dengan Kepuasan Kerja Sebagai Variabel Intervening. Thesis, Universitas Lampung.

Dharmanegara, Ida Bagus Agung. 2010. Penganggaran Perusahaan Teori dan Aplikasi. Yogyakarta: Graha Ilmu.

Eliana, Muhammad Arfan, dan Hasan Basri. 2014. Pengaruh Sistem Akuntansi Manajemen Dan Audit Internal Terhadap Kinerja Manajerial (Studi Pada Lembaga Keuangan Mikro Di Banda Aceh). Jurnal Magister Akuntansi. Pascasarjana Universitas Syiah Kuala. Volume 3, No. 3, Agustus 2014

Ermawati, Nanik. 2017. Pengaruh Partisipasi Anggaran Terhadap Kinerja Manajerial Dengan Motivasi Kerja Sebagai Variabel Pemoderasi (Studi Kasus Skpd Kabupaten Pati). Jurnal Akuntansi Indonesia, Vol. 6 No. 2 Juli 2017, Hal. 141 - 156.

Giusti, Giullerma., Alwan Sri Kustono dan Rochman Effendi. 2018. Pengaruh Partisipasi Anggaran Terhadap Kinerja Manajerial dengan Komitmen Organisasi dan Motivasi Sebagai Variabel Intervening. eJournal Ekonomi Bisnis dan Akuntansi, 2018, Volume V (2) : 121-128

Gunawan, Aditiya Christianto. 2015. Pengaruh Partisipasi Anggaran Terhadap Kinerja Manajerial Melalui Komitmen Organisasi Dan Motivasi Sebagai Variabel Moderating (Studi Empiris Pada Perusahaan Manufaktur di Jakarta dan Tangerang). Jurnal Akuntansi/Volume XIX, No. 01, Januari 2015: 144-159

Hafridebri. 2013. Pengaruh Partisipasi Anggaran Terhadap Kinerja Manajerial Melalui Komitmen
Tujuan Anggaran Dan Job Relevant Information Sebagai Variabel Intervening Pada Perusahaan Manufaktur Di Pekanbaru. Fakultas Ekonomi Universitas Negeri Padang.

Hanny. 2013. The Influence of Budgetary Participation on Managerial Performance at Banking Sector in Bandung And Cimahi City. International Conference on Business, Economics, and Accounting.

Horngren, Charles T, dkk. 2016. Pengantar Akuntansi Manajemen. Jilid 1. Edisi 16. Penerbit Erlangga

Ingkiriwang, Octavia Ferona. 2013. Pengaruh Desentralisasi dan Sistem Akuntansi Manajemen Terhadap Kinerja Manajerial Dealer Di Manado. ISSN: 2303-1174. Jurnal EMBA. Vol.1 No.3. Hal 818-825.

Iswahyudi. 2019. Pengaruh Partisipasi Anggaran Terhadap Kinerja Manajerial Dengan Motivasi Kerja Sebagai Variabel Pemoderasi (Studi Kasus Pada Organisasi Perangkat Daerah (OPD) Di Kota Jayapura). Jurnal Akuntansi \& Keuangan Daerah Volume 14, Nomor 1, Mei 2019: $120-138$

Jannah Miftahul, Sri Rahayu. 2015. Pengaruh Partisipasi Penganggaran terhadap Kinerja Manajerial SKPD dengan Kejelasan Sasaran Anggaran, Komitmen Tujuan Anggaran, Keadilan Distributif dan Pengawasan Internal sebagai Variabel Intervening. Jurnal Perspektif Pembiayaan Dan Pembangunan Daerah Volume 3 No.2 OktoberDesember 2015.

Kamilah, Faizah. 2013. Pengaruh Partisipasi Anggaran Terhadap Kinerja Manajerial Dengan Komitmen Organisasi Dan Gaya Kepemimpinan Sebagai Variabel Moderating (Studi Empiris Pada 
Rumah Sakit Di Pekanbaru). Jurnal SOROT Vol 8 No 2 Oktober hlm. 1 190 Lembaga Penelitian Universitas Riau.

Kholidah, Luluk Arifatul. 2014. Partisipasi Anggaran Terhadap Kinerja Manajerial: Komitmen Organisasi Dan Informasi Tugas Sebagai Pemediasi. Accounting Analysis Journal 3 (2) (2014)

Kumentas, Cynthia N. 2013. Pengaruh TQM, Sistem Pengukuran Kinerja, dan Penghargaan Terhadap Kinerja Manajerial Pada PT. Pos Indonesia. Jurnal EMBA. Vol. 1,(3), hlm 796805.

Lempas, Yuwinda. 2014. Desentralisasi Dan Sistem Akuntansi Manajemen Terhadap Kinerja Manajer Pada PT. Sinar Galesong Prima Manado. Jurnal EMBA. Vol.2 No.1 Maret 2014, Hal. 431 - 440.

Lina dan Stella. 2013. Pengaruh Partisipasi Penyusunan Anggaran Terhadap Kinerja Manajerial: Kepuasan Kerja dan Job Relevant Information Sebagai Variabel Intervening. Jurnal Bisnis dan Akuntansi, 15(1), pp: 37-56.

Mardiasmo. 2018. Akuntansi Sektor Publik.Yogyakarta: Andi.

Marthin, Titien., David P.E Saerang, Sifrid S. Pangemanan. 2013. Pengaruh Partisipasi Penyusunan Anggaran, Motivasi dan Pelimpahan Wewenang Terhadap Kinerja Manajerial Dinas Daerah Kabupaten kepulauan Siau Tagulandang Biaro. Jurnal Riset Akuntansi Going Concern, Vol. 8 No. 3, hlm 13-25.

Matana, Anastasia, 2017. Pengaruh Total Quality Management Terhadap Ekspektasi Kinerja Karyawan Pada PT. Pelabuhan Indonesia IV (Persero). Fakultas Ekonomi dan Bisnis, Universitas Hasanuddin, Makasar.
Milani, K. 1975. The Relationship of Participation in Budget-Setting to Industrial Supervisor Performance and Attitudes: A Field Study. The Accounting Review Volume 50, pp. 274-284.

Minai, Badriyah dan Mun, Mook P. 2013.Budget Adequacy and Organizational Commitment: Their Role In The Relationship Between Budget Participation and Managerial Performance. 2nd International Conference On Mnagement, Economics and Finance Proceeding.

Moheri, Yoyon. 2015. Pengaruh Partisipasi Anggaran Terhadap Kinerja Manajerial. EKOBIS Vol. 16, No.1, Januari 2015: 86 - 93

Nafarin, M. 2015. Penganggaran Perusahaan. Edisi tiga. Jakarta: Salemba Empat.

Nor, Wahyudi. 2007. Desentralisasi dan Gaya Kepemimpinan Sebagai Variabel Moderating dalam Hubungan antara partisipasi Anggaran dan Kinerja Manajerial. Jurnal Simposium Nasional Akuntansi X, pp. 25-52.

Nurhalimah. 2013. Pengaruh Partisipasi Penyusunan Anggaran dan Kejelasan Sasaran Anggaran terhadap Kinerja Aparatur Perangkat Daerah di Pemerintahan Aceh. e- Journal Akuntansi Universitas Syiah Kuala. (1) 2 : Banda Aceh.

Pratami, Indri Paundria Nagari. 2015. Pengaruh Sistem Informasi Akuntansi Manajemen Dan Budaya Organisasi Terhadap Kinerja Manajerial (Studi pada PT. Pos Indonesia (Persero) Kota Bandung Jawa

Barat). http://repository.unpas.ac.i d/5644/ diakses pada 5 Agustus 2019. 
Pratiwi, Wiwik. 2019. Pengaruh Akuntansi Pertanggungjawaban, Komitmen Organisasi, Dan Partisipasi Anggaran Terhadap Kinerja Manajerial. WAHANA Volume 22, No. 1, Februari 2019.

Putri, Anastasia. 2014. Pengaruh Partisipasi Anggaran Terhadap Kinerja Manajerial Dengan Pengetahuan Manajemen Biaya Sebagai Variabel Moderasi (Studi Kasus Pada PT. PINDAD (Persero) Bandung). e-Proceeding of Management: Vol.1, No.3 Desember 2014.

Putri, Zuwesty Eka dan Ricky Adiguna. 2014. Pengaruh Partisipasi Anggaran, Komitmen Organisasi, Gaya Kepemimpinan Terhadap Kinerja Manajerial, Jurnal Bisnis dan Manajemen, Vol. 4, No. 3.

Qibtiyah, Mariyatul. 2018. Pengaruh Desentralisasi Dan Sistem Akuntansi Manajemen Terhadap Kinerja Manajerial Pada Politeknik Kesehatan Siteba. https://osf.io/xut37/ diakses pada 5 Agustus 2019.

Rahayu, Sri dan Andry Arifian Rachman. 2013. Penyusunan Anggaran Perusahaan. Yogyakarta: Graha Ilmu

Rante, Andika., Rosidi Rosidi dan Ali Djamhuri. 2014. Sistem Akuntansi Manajemen, Gaya Kepemimpinan, Dan Desentralisasi Sebagai Determinan Kinerja Manajerial. Jurnal Akuntansi Multiparadigma. https://jamal.ub.ac.id/index.php/j amal/article/view/287 diakses pada 5 Agustus 2019.

Robbins, S. P. dan Judge, T. A. 2015.Perilaku Organisasi Edisi ke Enam Belas. Jakarta: Penerbit Salemba Empat.

Rudiantoro. 2013. Akuntansi Manajemen: Informasi untuk Pengambilan Keputusan Strategis. Erlangga
Setyolaksono, Bhakti. 2011. Pengaruh Desentralisasi dan Sistem Akuntansi Manajemen terhadap Kinerja Manajerial, Kasus pada Industri Es Balok di Kota Semarang. Skripsi Universitas Negeri Semarang: Semarang. Sianipar, Mawar Sari. 2018. Pengaruh Sistem Akuntansi Manajemen, Sistem Pengendalian Manajemen, Motivasi Dan Komitmen Organisasi Terhadap Kinerja Manajerial (Studi Empiris Pada PT. PLN Area Pekanbaru).Skripsi, Universitas Islam Negeri Sultan Syarif Kasim Riau.diakses pada 23 Agustus 2019.

Sianipar, Mawar Sari. 2018. Pengaruh Sistem Akuntansi Manajemen, Sistem Pengendalian Manajemen, Motivasi Dan Komitmen Organisasi Terhadap Kinerja Manajerial (Studi Empiris Pada PT. PLN Area Pekanbaru).Skripsi thesis, Universitas Islam Negeri Sultan Syarif Kasim Riau.

Sigillipu, Steffi. 2013. Pengaruh Penerapan Informasi Akuntansi Manajemen dan Sistem Pengukuran Kinerja Terhadap Kinerja Manajerial. ISSN: 2303- 1174. Jurnal EMBA. Vol. 1No.3 Juni 2013. Hal 239-247.

Solikah, Duwi. 2017. Pengaruh Karakteristik Broad Scope Sistem Akuntansi Manajemen Terhadap Kinerja Manajerial Dengan Ketidakpastian Lingkungan Dan Desentralisasi Sebagai Variabel Moderating (Studi Empiris Pada Bank Yang Ada Di Ponorogo). Skripsi. Universitas Muhammadiyah Ponorogo.

Srimindarti, Ceacilia. 2012. Faktor-faktor yang Mempengaruhi Premature SignOff dengan Turnover Intention sebagai Variabel Intervening: Suatu Tinjauan dari Goal Setting Theory. Jurnal Organisasi dan Manajemen. Vol. 8, No. 2, Hal. 102-110. 
Sulani, Sri. 2013. Pengaruh Karakteristik Sistem Akuntansi Manajemen Terhadap Kinerja Manajerial (Studi Kasus BPR Di Kabupaten Demak). Jurnal Akuntansi Indonesia, Vol. 3 No. 2 Juli 2013, Hal. 97 - 111.

Sulijaya, Feliana \&Nuraini Bangun. 2015. Pengaruh TQM, Motivasi Dan Komitmen Organisasi Terhadap Kinerja Manajerial. Jurnal Akuntansi Vol. XIX No. 03 September 2015, hlm 433-448.

Syafira, Amalia. 2015. Pengaruh Sistem Akuntansi Manajemen (SAM) terhadap Kinerja Manajerial dengan Sistem Pengukuran Kinerja dan Sistem Reward sebagai Variabel Moderating (Studi Empiris pada Perusahaan BUMN Kota Padang).

http://ejurnal.bunghatta.ac.id/ind ex.php?journal=JFEK\&page $=$ article \&op=view\&path\%5B\%5D=4748 diakses pada 5 Agustus 2019.

Tapatfeto, Jasintha Dessy. 2014. Job Relevant Information Desentralisasi Dan Partisipasi Anggaran Terhadap Kinerja Manajerial. Ekuitas: Jurnal Ekonomi dan Keuangan - Volume 18, Nomor 2, Juni 2014: 219 - 241

Wibowo. 2010. Manajemen Kinerja. Jakarta: PT. Raja Grafindo Persada.

Wibowo, Prayoga. 2017. Pengaruh Partisipasi Anggaran Dan Komitmen Organisasi Terhadap Kinerja Manajerial. Skripsi. Universitas Hasanuddin. Makassar.

Windasari, Putu Agustina., dan I Ketut Sujana. 2016. Pengaruh Penganggaran Partisipatif Pada Kinerja Manajerial Dengan Karakteristik Sistem Akuntansi Manajemen Sebagai Pemoderasi. EJurnal Akuntansi Universitas Udayana. Vol.15, No. 2. Mei (2016): 1282-1309.

Wulandari, N., \& Santoso, S. 2013. Pengaruh Sistem Akuntansi
Manajemen, dan Desentralisasi Terhadap Kinerja Manajerial Pada Pegawai Kantor Pemerintah DaerahKabupaten Ngawi. Jurnal Akuntansi.

Yuliana., Nadirsyah dan Umar Bakar. 2012. Pengaruh Penerapan Total Quality Management Terhadap Kinerja Manajerial Dengan Budaya Organisasi, Sistem Pengukuran Kinerja dan Sistem Penghargaan Sebagai Variabel Moderating (Studi Empiris Pada Manajer Bank-Bank Yang Beroperasional Di Banda Aceh). Jurnal Akuntansi. Volume 2, No. 1, November 2012. Hal. 127141.

Yuwinda Lempas,Ventje Ilat,Harijanto Sabijono. 2014. Desentralisasi dan Sistem Akuntansi Manajemen Terhadap Kinerja Manajer Pada PT Sinar Galesong Prima Manado. ISSN: 2303-1174. Jurnal EMBA. Vol. 2 No. 1 Maret 2014. hal 431-440. 